\title{
Signaling Pathways Involved in Mammalian Sex Determination and Gonad Development
}

\author{
Simon P. Windley ${ }^{a}$ Dagmar Wilhelm ${ }^{a, b}$ \\ ${ }^{a}$ Department of Anatomy and Neuroscience, The University of Melbourne, Parkville, Vic., and bepartment of \\ Anatomy and Developmental Biology, Monash University, Clayton, Vic., Australia
}

\section{Key Words}

Embryogenesis - Gonadogenesis · Sex determination .

Signaling pathways $\cdot$ Signal transduction

\begin{abstract}
The development of any organ system requires a complex interplay of cellular signals to initiate the differentiation and development of the heterogeneous cell and tissue types required to carry out the organs' functions. In this way, an extracellular stimulus is transmitted to an intracellular target through an array of interacting protein intermediaries, ultimately enabling the target cell to elicit a response. Surprisingly, only a small number of signaling pathways are implicated throughout embryogenesis and are used over and over again. Gonadogenesis is a unique process in that 2 morphologically distinct organs, the testes and ovaries, arise from a common precursor, the bipotential genital ridge. Accordingly, most of the signaling pathways observed throughout embryogenesis also have been shown to be important for mammalian sex determination and gonad development. Here, we review the mechanisms of signal transduction within these pathways and the importance of these pathways throughout mammalian gonad development, mainly concentrating on data obtained in mouse but including other species where appropriate.

(c) 2016 S. Karger AG, Basel
\end{abstract}

Cellular signaling is crucial to life. Throughout development, cells must communicate in order to coordinate the differentiation of a vast array of heterogeneous cell types within any given organ system. Additionally, cellular interactions within the mature organism are necessary in order to maintain homeostasis and carry out day-today functions. Typically, these interactions occur as a result of induction, wherein a cell releases a signal to induce a change in another cell. A cell's competence, that is its ability to elicit a cellular change in response to a signal, is largely dependent on the presence or absence of a signaling receptor. Binding of this receptor by its ligand leads to receptor activation, resulting in the recruitment of protein intermediaries responsible for transducing the signal within the intracellular signaling cascades. In many cases this ultimately results in the activation of transcription factors, causing a change in gene expression, which dictates cell fate decision, differentiation, proliferation, migration, and apoptosis.

Despite the importance of signaling in all cellular processes, the number of signaling pathways identified to date that have been implicated throughout embryogenesis is limited; however, there is a substantial amount of cross-talk between these pathways. Integration and divergence of these pathways is vital throughout development to ensure that target cells interpret and respond to con-

\section{KARGER 125}

(c) 2016 S. Karger AG, Base

1661-5425/16/0096-0297\$39.50/0 
text-dependent cues. Consequently, the cumulative effect of combined pathways may result in a response far different than the sum of its parts. Furthermore, many of these pathways elicit their effects in a dose-dependent manner and as such the time, location, and duration of signaling largely affects the nature of the response.

Gonadogenesis is a unique and complex process wherein morphologically distinct organs, testes and ovaries, arise from a common precursor. Since the discovery of the male-determining gene $S R Y$ in 1990, much research has gone into elucidating the mechanisms of sex determination and gonad differentiation. Given the importance of cell signaling throughout embryogenesis, it is not surprising that most of the signaling cascades characterized to date have been implicated in this process. However, there is a lack of knowledge regarding the importance of their cross-talk and cumulative effects during gonad development. In this review we will first summarize the cellular and morphological mechanisms underlying mammalian sex determination and gonad development before describing in detail the mechanisms of signal transduction pathways involved throughout these processes.

\section{Cellular and Morphological Events during Mammalian Gonad Development}

The development of both testes and ovaries starts with the the same precursor structures, the genital ridges. First described in 1870 [Waldeyer, 1870], the genital ridges develop through thickening and proliferation of the surface epithelium on the ventromedial side of the mesonephros at around 9.5 days post coitum (dpc) in mice and during the fourth week of gestation in humans [Byskov, 1986]. These somatic cells are joined by primordial germ cells (PGCs) that have made their journey from the base of the allantois [Anderson et al., 2000] where they have been specified as a result of inductive signaling at approximately $7.0 \mathrm{dpc}$ in mice [Lawson et al., 1999] and during the third week of gestation in humans [Ginsburg et al., 1990]. Mouse PGCs reach the developing genital ridges at around 10.0 dpc [Tam and Snow, 1981; McLaren, 1984]. They proliferate rapidly with incomplete cytokinesis, thus forming germ cell cysts in both XX and XY developing gonads [Pepling and Spradling, 1998; Lei and Spradling, 2013]. In the mouse these germ cell cysts are not maintained but instead they fragment into smaller cysts and single germ cells during development [Lei and Spradling, 2013].
The genital ridges remain indistinguishable between males and females until approximately $12.0 \mathrm{dpc}$. After this, the developing testis shows massive morphological changes which are induced by the key regulator of sex determination in mammals, the sex-determining region on the Y chromosome gene Sry, the founding member of the family of Sox genes encoding HMG (high mobility group)-domain transcription factors [Bowles et al., 2000]. Gain-of-function experiments in which Sry was introduced into XX mice [Koopman et al., 1991] and experiments utilizing sex-reversed XY mice with mutations in the sex-determining region Tdy [Gubbay et al., 1990] demonstrated that SRY is both sufficient and necessary for testis development.

\section{Testis Development}

Sry is expressed in the supporting cell precursors and drives their differentiation into Sertoli cells [Sekido et al., 2004]. First described in 1865, Sertoli cells are nurse cells with the primary function of supporting germ cells [Sertoli, 1865]. It is believed that the origin of Sertoli cell precursors lies within the coelomic epithelium [Karl and Capel, 1998] and that these pre-Sertoli cells generate signals to induce proliferation within the $\mathrm{XY}$ genital ridge, thus producing more Sertoli cells [Schmahl et al., 2000]. This may dictate the fertility of the individual as Sertoli cells only proliferate during fetal and early neonatal development [Orth, 1982], and the final number of Sertoli cells in the adult dictates the number of germ cells that can be supported [Sharpe et al., 2003].

As Sertoli cells differentiate they assume a polarized morphology and extend cytoplasmic protrusions around germ cells to form testis cords [Combes et al., 2009]. Testis cords are the precursor of the seminiferous tubules in adult testes, which ultimately play a role in sperm maturation and transport. Testis cords form over a 24 -hour period from 11.5 to $12.5 \mathrm{dpc}$ in mice [Coveney et al., 2008] and between weeks 7 and 8 of human gestation [Hanley et al., 2000]. In this time, Sertoli cells surround germ cells to form aggregates of cells. Following this, endothelial cells from the mesonephros migrate into the developing testis and segregate these Sertoli/ germ cell clusters into evenly distributed cords throughout the testis [Combes et al., 2009]. Later during development, the testes enlarge and testis cords elongate, eventually forming the seminiferous tubules. PGCs within the testis cords will enter mitotic arrest from around $13.5 \mathrm{dpc}$ [Western et al., 2008, 2011] and only re-enter the cell cycle after birth to start the process of spermatogenesis. 
Sertoli cells instruct interstitial mesenchymal cells to differentiate into peritubular myoid (PM) cells. These cells surround the testis cords, forming a single layer in mice [Gardner and Holyoke, 1964] and 3-4 layers in humans [Ross and Long, 1966]. Extracellular matrix proteins, secreted by both PM and Sertoli cells, form a basal lamina between these 2 cell types [Skinner et al., 1985] that is important for the integrity of testis cords. PM cells become contractile later in development, which is necessary for the transport of sperm from the testis into the epididymis [Ellis et al., 1981; Maekawa et al., 1996]. At around the same time (from $12.5 \mathrm{dpc}$ ), fetal Leydig cells differentiate from interstitial mesenchymal precursor cells. First described in 1850 [Leydig, 1850], Leydig cells are largely responsible for the production of androgens that are important for virilisation of the reproductive tract and development of secondary sexual characteristics [Geissler et al., 1994].

\section{Ovarian Development}

In contrast to the developing testis, morphological changes in the developing ovary have a later onset, with the developing ovary being in an apparently inert state until approximately $13.5 \mathrm{dpc}$. At this stage, germ cells at the anterior pole start entering meiosis, followed by other germ cells in an anterior-to-posterior order [Menke et al., 2003; Yao et al., 2003; Bullejos and Koopman, 2004]. Germ cells within a cyst, and even within different fragments of the same cyst, enter meiosis synchronously [Lei and Spradling, 2013]. By $15.5 \mathrm{dpc}$, most germ cells have entered meiosis and arrest in prophase I [Borum, 1961; Miles et al., 2010]. In addition, many germ cells are lost through apoptosis. The remaining cells will form primordial follicles, single oocytes surrounded by a single layer of flattened granulosa cells, shortly after birth in mouse [Epifano and Dean, 2002] and from week 21 in human gestation, being completed at birth [Gougeon, 1996]. In mouse there are 2 types of follicles: medullary follicles that are activated shortly after birth and contribute to puberty and early fertility, and cortical follicles that are activated gradually throughout life [Mork et al., 2012; Zheng et al., 2014]. It is unclear if these 2 populations of follicles also exist in human. However, it has been shown that growing follicles exist in the medullary region throughout infancy and childhood [Lintern-Moore et al., 1974; Peters et al., 1976], suggesting that the mouse ovary reflects the situation in the human ovary. In accordance with the presence of the 2 types of follicles, 2 classes of pre-granulosa cells can be found in the fetal ovary, medullary and cortical pre-granulosa cells, which might arise from a sin- gle precursor cell lineage [Mork et al., 2012; Hummitzsch et al., 2013] but are distinguishable by marker gene expression from $13.5 \mathrm{dpc}$ [Rastetter et al., 2014]. The assembly of the follicles is completed by the recruitment of steroidogenic precursor cells to differentiate into theca cells [Hirshfield, 1991]. Recently, it has been shown that there are 2 sources of theca cell precursors: mesenchymal cells that reside within the ovary and a second population that migrates into the ovary from the mesonephros [Liu et al., 2015].

\section{Importance of Signaling Pathways in Embryogenesis}

The formation of any organ in the body depends on cell-cell communication to accomplish the coordinated differentiation and development of different cell types and tissues. This cell-cell communication is achieved by signaling pathways by which one type of cell generates a signal that is received by other cells that are competent to respond [Spemann and Mangold, 1924; Waddington, 1940]. Surprisingly, only a small number of signaling pathways are involved in organogenesis, including WNT (wingless-type MMTV integration site family), NOTCH, TGF $\beta$ (transforming growth factor beta), which includes BMPs (bone morphogenetic proteins), $\mathrm{HH}$ (hedgehog), Hippo, nuclear receptors, for example the retinoic acid receptor (RAR), and RTKs (receptor tyrosine kinases) such as FGFR (fibroblast growth factor receptor), EGFR (epidermal growth factor receptor), and IR (insulin receptor). Activation initiates a signaling cascade within the receiver cell that usually results in a change of gene expression. Accordingly, the effectors of these pathways are mainly transcription factors at promoters and enhancers of genes. However, signaling pathways also regulate the function of other proteins involved in transcriptional regulation, such as RNA polymerase II, histones, and histone modifying enzymes, as well as chromatin remodeling complexes [for reviews see Klein et al., 2013; Yang et al., 2013].

Almost all of the above-mentioned signaling pathways have been shown to play a role during sex determination and gonad development. Only the Hippo pathway, which was originally identified in Drosophila for its role in controlling organ size [Pan, 2010], has not been implicated to date. In the following sections we will discuss the molecular mechanisms of how these signaling pathways function and what role they play during mammalian gonad development (see also table 1). 
Table 1. Signaling components involved in different stages of gonad development. Loss-of-function phenotypes in the fetal gonads, observed through mouse knockout models and/or the use of inhibitors in ex vivo gonad cultures of different signal pathway components

\begin{tabular}{|c|c|c|}
\hline Component & Loss-of-function phenotype & Reference \\
\hline GADD $45 \gamma$ & $\begin{array}{l}\text { XY gonadal sex reversal caused by reduced phosphorylation of p38alpha MAPK and GATA4 } \\
\text { and therefore a lack of Sry expression }\end{array}$ & Gierl et al. [2012]; Warr et al. [2012] \\
\hline MAP3K4 & $\mathrm{XY}$ gonadal sex reversal caused by a dramatic reduction in Sry and Sox 9 expression & Bogani et al. [2009] \\
\hline INSR/IGF1R/IRR & XY gonadal sex reversal due to a delay/lack of Sry upregulation & Nef et al. [2003]; Pitetti et al. [2013] \\
\hline FGFR2 & $\begin{array}{l}\text { background-dependent partial to complete male-to-female sex reversal due to failure to } \\
\text { maintain Sox9 expression }\end{array}$ & $\begin{array}{l}\text { Kim et al. [2007]; Bagheri-Fam et al. } \\
{[2008,2015] \text {; Siggers et al. [2014] }}\end{array}$ \\
\hline BMP7 & $\begin{array}{l}\text { significant reduction in PGC numbers of both } \mathrm{XX} \text { and } \mathrm{XY} \text { at } 11.5 \mathrm{dpc} \text { as a result of reduced } \\
\text { germ cell proliferation }\end{array}$ & Ross et al. [2007] \\
\hline
\end{tabular}

\section{Testis differentiation}

WNT4 compromised Sertoli cell differentiation at early stages and therefore delayed sex cord

formation, suggesting a testicular role for WNT4 downstream of Sry but upstream of Sox9

WNT5a hypoplastic testes at early stages caused by a decrease in somatic cell proliferation

$\mathrm{DHH}$ defects in fetal and adult Leydig and peritubular myoid cell differentiation, anastomotic testis cords

HHAT

reduction in testis size from $12.5 \mathrm{dpc}$ with a decrease in testis cord number and alteration in size and shape of testis cords, as well as a lack of Leydig cell differentiation

HES1 increase in Leydig cell numbers, abnormal testis cord formation as well as germ cell loss. In contrast, constitutively active Notch signaling results in Leydig cell loss

ALK4/5/7 and reduction in Sertoli cell proliferation and therefore disrupted testis cord formation; PGCs ALK5 alone Activin $\beta$ A enter meiosis instead of mitotic arrest

reduction in Sertoli cell proliferation at $13.5 \mathrm{dpc}$ and therefore a failure in fetal testis cord elongation

SMAD4

knockout specifically in Sertoli cells results in a similar phenotype as activin $\beta$ A with reduced Sertoli cell proliferation and failed testis cord elongation; knockout in PGCs causes entry into meiosis instead of mitotic arrest in some PGCs

SMAD2 PGC-specific knockout results in downregulation of Nodal and Nanos2 and therefore a defect in male germ cell differentiation.

TGF 32 transient reduction in testis cord number

TGFBR3

defect in testis cord formation at early stages and reduced fetal Leydig cell function

defects in cell proliferation and endothelial cell migration from the mesonephros and therefore defective testis cord formation. In addition, fetal Leydig cell differentiation is impaired

PTGDS transient abnormal SOX9 protein localization in cytoplasm and reduced Sox9 mRNA levels, causing a delay in testis cord formation, which recovered at later stages

HPGDS defect in initial SOX9 translocation into the nucleus at $11.5 \mathrm{dpc}$

PTGDS/HPGDS phenotype in somatic cells is similar to PTGDS single knockout; however, in addition, the double knockout displays a significant increase in germ cell proliferation due to the regulation of cell cycle genes by $\mathrm{PGD}_{2}$

DP2 same phenotype as PTGDS/HPGDS double knockout, showing that $\mathrm{PGD}_{2}$ acts through DP2 receptor

FGF9 male-specific reduction in germ cell number due to elevated apoptosis

p38 MAPKs PGCs in a testis enter meiosis instead of mitotic arrest, suggesting p38 inhibits RA signaling

\section{Ovary differentiation}

INSR/IGF1R delay in ovarian differentiation in XX and XY mutant gonads

$\beta$-Catenin partial female-to-male sex reversal with the formation of a coelomic vessel, androgenproducing, adrenal-like cells and loss of germ cells; in addition, Wnt4 expression was reduced, but Rspo1 unaffected

RSPO1 partial female-to-male sex reversal with the formation of a coelomic vessel, androgenproducing, adrenal-like cells and loss of germ cells due to a decrease in proliferation; in addition, granulosa cells differentiate prematurely and trans-differentiate into Sertoli-like cells postnatally

WNT4 partial female-to-male sex reversal with the formation of a coelomic vessel, androgenproducing, adrenal-like cells and loss of germ cells due to an increase in apoptosis; in addition, granulosa cells differentiate prematurely and trans-differentiate into Sertoli-like cells postnatally

FST
Jeays-Ward et al. [2004]

Chawengsaksophak et al. [2012]

Bitgood et al. [1996]; Clark et al. [2000]; Pierucci-Alves et al. [2001]; Yao and Capel [2002]; Yao et al. [2002] Callier et al. [2014]

Tang et al. [2008]

Miles et al. [2013]; Wu et al. [2013]

Archambeault and Yao [2010];

Mendis et al. [2011]

Archambeault and Yao [2010];

Wu et al. [2015]

Wu et al. [2015]

Memon et al. [2008]

Sarraj et al. [2010]

Brennan et al. [2003]

Moniot et al. [2009]

Moniot et al. [2011]

Moniot et al. [2014]

Moniot et al. [2014]

DiNapoli et al. [2006]

Ewen et al. [2010]; Wu et al. [2015]

Pitetti et al. [2013]

Liu et al. [2009]

Chassot et al. [2008, 2012]; Tomizuka et al. [2008]; Maatouk et al. [2013]

Vainio et al. [1999]; Jeays-Ward et al. [2003]; Maatouk et al. [2013]

Yao et al. [2004] 


\section{Signaling Pathways Regulating Genital Ridge Formation and Sex Determination}

During the early stages, $\mathrm{XX}$ and $\mathrm{XY}$ genital ridges increase in size through proliferation of somatic cells within or near the coelomic epithelium [Schmahl et al., 2000]. This proliferation is dependent on WNT signaling (fig. 1A) [Chassot et al., 2012], with 2 ligands of the WNT signaling pathway being expressed: WNT4 (winglesstype MMTV integration site family, member 4) [Nusse et al., 1991] and RSPO1 (R-spondin homolog 1) [Kamata et al., 2004]. Null mutations of Wnt4 or Rspo 1 in mouse result in a reduction of proliferation in the developing genital ridges of both sexes, especially within the coelomic epithelium [Chassot et al., 2012].

The canonical WNT signaling pathway is crucial throughout embryonic development as a mediator of cellular differentiation and morphogenesis. Activation of this pathway ultimately leads to the accumulation and nuclear translocation of $\beta$-catenin, which acts as a co-activator of the transcription factors TCF/LEF (T cell factor/lymphoid enhancer factor). All TCF/LEFs bind to the DNA through a HMG domain that also induces bending of the DNA [Giese et al., 1991; Love et al., 1995]. These factors repress the transcription of target genes in the absence of active WNT signaling by interacting with co-repressors such as members of the AES (amino terminal enhancer of split, also called Groucho-related gene, GRG)/TLE (transducing-like enhancer of split) family. Interaction of TCF/LEF with $\beta$-catenin removes these corepressors and enables transcription of WNT target genes [for reviews, see Miller and Moon, 1996; Clevers and Nusse, 2012]. The signal transduction components that link the WNT receptors complex FZD (frizzled)/LRP6 or LRP5 to $\beta$-catenin is the $\beta$-catenin destruction complex, which consists of the scaffold protein AXIN1, the tumor suppressor APC (adenomatous polyposis coli), CSNK1 (casein kinase 1), and GSK3 (glycogen synthase kinase 3). In the absence of ligand binding, CSNK1 and GSK3 phosphorylate $\beta$-catenin, which results in the recruitment of an E3 ubiquitin ligase and subsequent targeting of $\beta$-catenin for proteasomal degradation by ubiquitination [Aberle et al., 1997]. Upon WNT ligand binding to its receptors, the scaffolding protein DVL1 (dishevelled) is recruited, leading to the phosphorylation of LRP6 and the translocation of the destruction complex away from cytoplasmic $\beta$-catenin to the membrane-bound receptors. This disruption of the association of $\beta$-catenin with the destruction complex ultimately leads to the accumulation of $\beta$-catenin in the cytoplasm and translocation to the nu-

Signaling during Gonad Development cleus to act as a transcriptional co-activator [for review see Bienz and Clevers, 2003; Mosimann et al., 2009].

In addition to WNT4 and RSPO1, a knockout mouse model of another signaling pathway, namely the double deletion of the receptor tyrosine kinases INSR (insulin receptor) and IGF1R (insulin-like growth factor 1 receptor), also displays a reduction in proliferation in $\mathrm{XX}$ and XY genital ridges [Pitetti et al., 2013]. Interestingly, there appears to be cross-talk between these 2 pathways (fig. 1A), as Wnt4 expression is significantly reduced in the Insr/Igf1 $r$-null genital ridges [Pitetti et al., 2013], and Igfl $r$ expression is greatly reduced in the Rspo1- and Wnt4-null gonads [Chassot et al., 2012].

Things change quickly in the developing testis through the upregulation of the male-determining gene Sry from the Y chromosome (fig. 1B). Recently, the combination of several studies nicely demonstrated that this upregulation is under the control of a signaling pathway involving MAP (mitogen-activated protein) kinases. The MAPK cascades control proliferation, differentiation, and apoptosis of cells. Each MAPK pathway is a conserved cascade of 3 protein kinases. A breadth of differing extracellular stimuli, including mitogens, cytokines, growth factors, and cellular stressors, such as heat shock and UV irradiation, induce these pathways through the activation of a MAP kinase kinase kinase (MAP3K). MAP3Ks, in turn, phosphorylate and activate specific MAP kinase kinases (MAP2Ks), which then activate MAP kinases (MAPKs). The 3 conventional MAPK pathways described to date are the extracellular signal-regulated protein kinases (ERK1 and ERK2), cJUN N-terminal kinases (JNK1, JNK2 and JNK3), and the p38 MAP kinases (p38a, p38ß, $\mathrm{p} 38 \gamma, \mathrm{p} 38 \delta)$. These kinases activate and regulate the activities of a number of downstream target regulatory proteins and transcription factors. In addition, the 3 MAPK signaling pathways are not isolated, but there is considerable cross-talk between these pathways, and as such these cascades share some of their components.

Through the use of a forward genetic screen, Bogani et al. [2009] identified a recessive mouse mutant, named boygirl (byg), which exhibited XY gonadal sex reversal as a result of a mutation leading to a premature stop codon in the $M a p 3 k 4$ gene. The role of MAP3K4 in murine sex determination was further supported by the analysis of Gadd45g (growth arrest and DNA damage response) [Gierl et al., 2012; Warr et al., 2012]. GADD45 $\gamma$ disrupts the auto-inhibitory domain of MAP3K4, thereby inducing auto-phosphorylation and activation of MAP3K4 [Miyake et al., 2007], which in turn activates the downstream p38 MAP kinases [Takekawa et al., 1997]. p38 MAPKs then phos- 
Fig. 1. Signaling pathways involved in genital ridge proliferation and the regulation of Sry expression. A At $9.5 \mathrm{dpc}$, WNT signaling, activated by WNT4 and RSPO1, as well as insulin signaling through the receptors INSR and IGF1R, results in rapid proliferation of somatic cells in the early genital ridges, with cross-talk existing between these 2 pathways. B At $10.5 \mathrm{dpc}$, MAPK signaling plays a crucial role in upregulating Sry expression. In this way, GADD $45 \gamma$, possibly activated by insulin signaling, disrupts the auto-inhibitory domain of MAP3K4, inducing its auto-phosphorylation and activation, ultimately resulting in the activation of the downstream p38 MAP kinases via a MAP2K. However, it is not yet known which MAP2K is important in this regulation. p38 MAPKs then activate GATA4 which, in conjunction with its cofactor FOG2, binds to the Sry promoter activating Sry transcription and initiation of testis differentiation. C SRY, in conjunction with SF1, directly upregulates Sox9 transcription. In order to maintain Sox9 expression, 2 positive feedback loops are established. First, SOX9 upregulates Fgf 9 enabling the FGF9 protein to signal through its receptor FGFR2 to maintain Sox9 expression. Secondly, SOX9 upregulates Ptgds expression, which results in the production of $\mathrm{PGD}_{2}$. This ultimately leads to nuclear translocation of the SOX9 protein where it can maintain its own expression by binding its own promoter in conjunction with SF1.

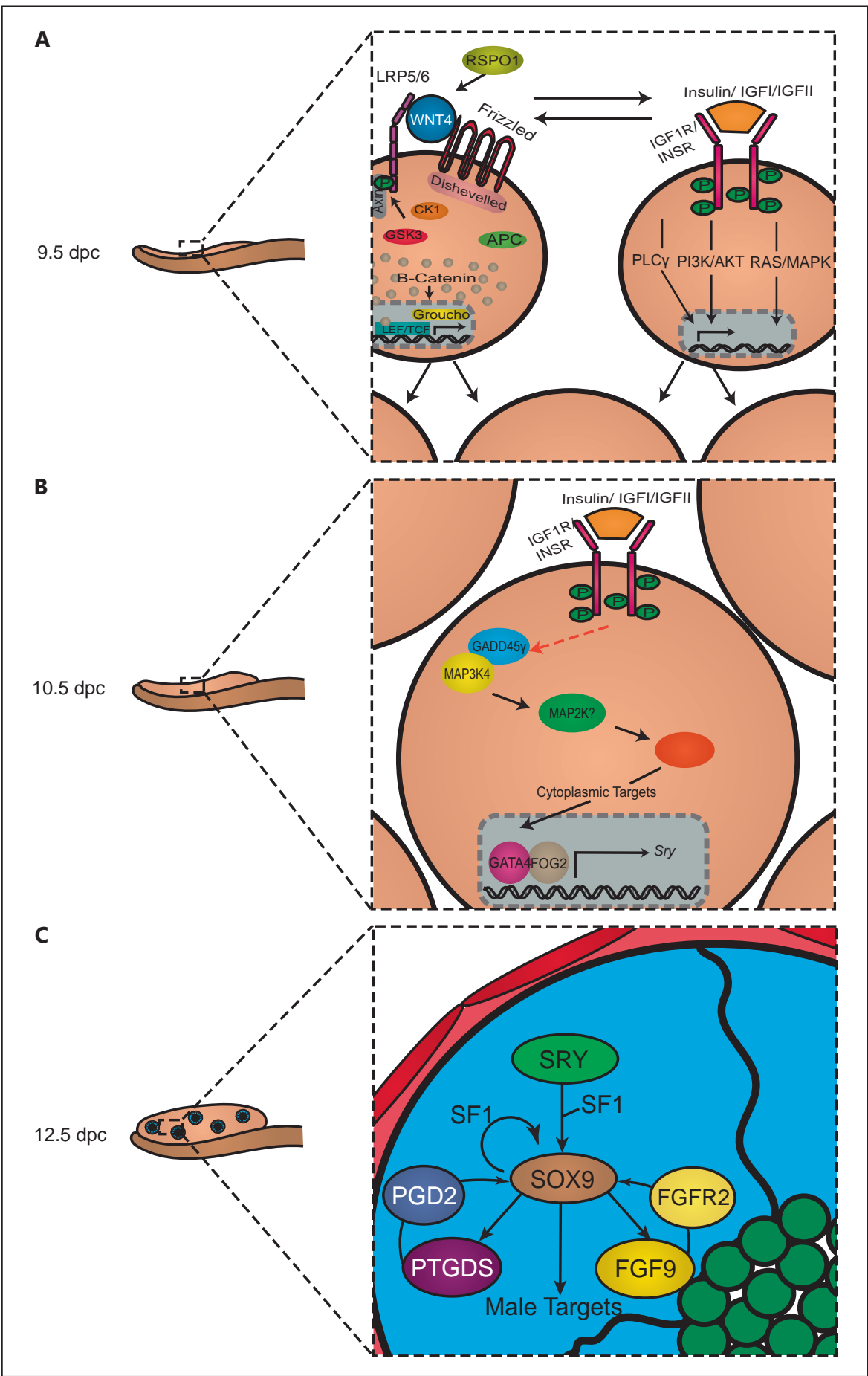

phorylate and activate the transcription factor GATA4 [Gierl et al., 2012; Warr et al., 2012], which, together with its co-factor FOG2, binds to the Sry promoter [Gierl et al., 2012], resulting in the upregulation of Sry transcription and therefore the induction of the testis differentiation program (fig. 1B) [Gierl et al., 2012; Warr et al., 2012]. Conse- quently, if any one of these factors is mutated in mouse, male-to-female sex reversal is observed due to reduced Sry expression [Tevosian et al., 2002; Miyamoto et al., 2008; Bogani et al., 2009; Gierl et al., 2012; Warr et al., 2012].

Nonetheless, the question still remains as to what causes the testis-specific upregulation of Gadd45g. GADD45 
proteins have been implicated in signaling in response to physiological and environmental stress including methylating agents such as methylmethanosulfonate, $\gamma$ and UV irradiation, as well as inflammatory cytokines such as IL2 and IL6 [Beadling et al., 1993; Liebermann and Hoffman, 1998; Zhang et al., 1999]. Possible inducers of Gadd $45 g$ during testis determination are the insulin receptors (fig. 1B). It has been shown that the combined null mutation of Insr and Igf1r [Pitetti et al., 2013] or the triple mutation also including Irr (insulin receptor-related receptor) [Nef et al., 2003] leads to reduced Sry expression and consequently male-to-female sex reversal. Interestingly, the Ir/Igf1r-double knockout also displayed reduced expression of Gadd45g [Pitetti et al., 2013], suggesting that this could be the cause of decreased Sry levels. It would be interesting to test if overexpression of Gadd $45 \mathrm{~g}$ can rescue the sex reversal phenotype caused by the loss of the insulin receptors.

In contrast in humans, mutations in a gene encoding another MAP3K, namely MAP3K1, result in 46,XY DSD with partial or complete gonadal dysgenesis [Pearlman et al., 2010]. Interestingly, the identified mutations seem to result in a gain- rather than loss-of-function of the MAP3K1 protein shown by an increase in phosphorylation of the downstream kinases p38 and ERKs as well as an increase in binding to interacting factors such as RHOA and AXIN1 [Pearlman et al., 2010; Loke et al., 2014]. Over-expression of the mutated MAP3K1 proteins in the human pluripotent testicular embryonic carcinoma cell line NT2/D1 resulted in a decrease in expression of genes associated with testicular differentiation such as $S R Y$, SOX9, and FGF9, as well as an increase in gene expression that is usually associated with ovarian development including WNT4, $\beta$-catenin, and FOXL2 [Loke et al., 2014]. However, it remains to be tested if the mutated MAP3K1 proteins are sufficient to also tilt this balance of the sex differentiation pathways in vivo by, for example, generating knock-in mouse models. Certainly the opposite, i.e. loss-of-function mutations in Map3k1, does not result in any significant defects in testis differentiation [Warr et al., 2011], demonstrating that Map3k1 is not necessary for murine testis determination.

\section{Control of Testis Development}

The expression of Sry in the developing testis causes a rapid increase in proliferating somatic cells, while the rate remains unchanged in the developing ovary [Schmahl et al., 2000]. This increase in proliferation is one of the ear- liest events after the expression of Sry. SRY has been shown to directly upregulate the related factor SOX9 [Sekido and Lovell-Badge, 2008], which in turn leads to the upregulation of the proliferation-promoting factor FGF9 (fig. 1C) [Colvin et al., 2001; Schmahl et al., 2004; Kim et al., 2006, 2007; Bagheri-Fam et al., 2008; Bradford et al., 2009].

The FGF family of signaling molecules consists of 18 ligands (FGF1-10 and FGF16-23) in mice and humans, which signal through 4 tyrosine kinase receptors FGFR14 [for review see Thisse and Thisse, 2005; Turner and Grose, 2010]. To signal, FGF ligands are released, they bind to heparin sulphate proteoglycans on the cell surface, and form a dimer with another FGF ligand [Yayon et al., 1991]. These ligands then bind the extracellular immunoglobulin domains of an FGFR enabling dimerization of the receptor, which brings the intracellular domains of each FGFR into close proximity, causing the trans-phosphorylation of critical tyrosine residues, thereby initiating signaling [Plotnikov et al., 1999; Schlessinger et al., 2000]. The predominant signaling cascades used by FGFRs are the RAS/MAPK pathways, but they also activate the PI3K (phosphatidylinositol 3-kinase)/AKT (thymoma viral proto-oncogene) and the PLC $\gamma$ (phospholipase $C \gamma$ ) pathways.

FGF9, directly or indirectly upregulated by SOX9 in the developing testis [Kim et al., 2006], signals through FGFR2 to maintain Sox9 expression [Bagheri-Fam et al., 2008; Kim et al., 2007], thereby forming a positive feedback loop (fig. 1C). Mice homozygous for a null mutation in Fgf9 or Fgfr 2 exhibit male-to-female sex reversal, with all testis-specific cellular events being disrupted, including cell proliferation, mesonephric cell migration, Sertoli cell differentiation, and testis cord formation [Colvin et al., 2001; Kim et al., 2007; Bagheri-Fam et al., 2008; Siggers et al., 2014]. Accordingly, mutations in FGFR2 in human have been identified that result in 46,XY DSD [Bagheri-Fam et al., 2015]. Interestingly, there are 2 alternative splice forms of FGFR2, FGFR2b and FGFR2c, affecting the extracellular domain and therefore ligand binding [Zhang et al., 2006]. These splice forms are expressed in a cell-specific manner, with the $b$ isoform predominantly expressed in epithelial cells and the $c$ isoform in mesenchymal cells [Gilbert et al., 1993; Orr-Urtreger et al., 1993; Yan et al., 1993; Alarid et al., 1994]; however, to date it is only known that FGFR2c is important for FGF9 signaling in the developing testis [Bagheri-Fam et al., 2015] but not if FGFR2b also plays a role. 


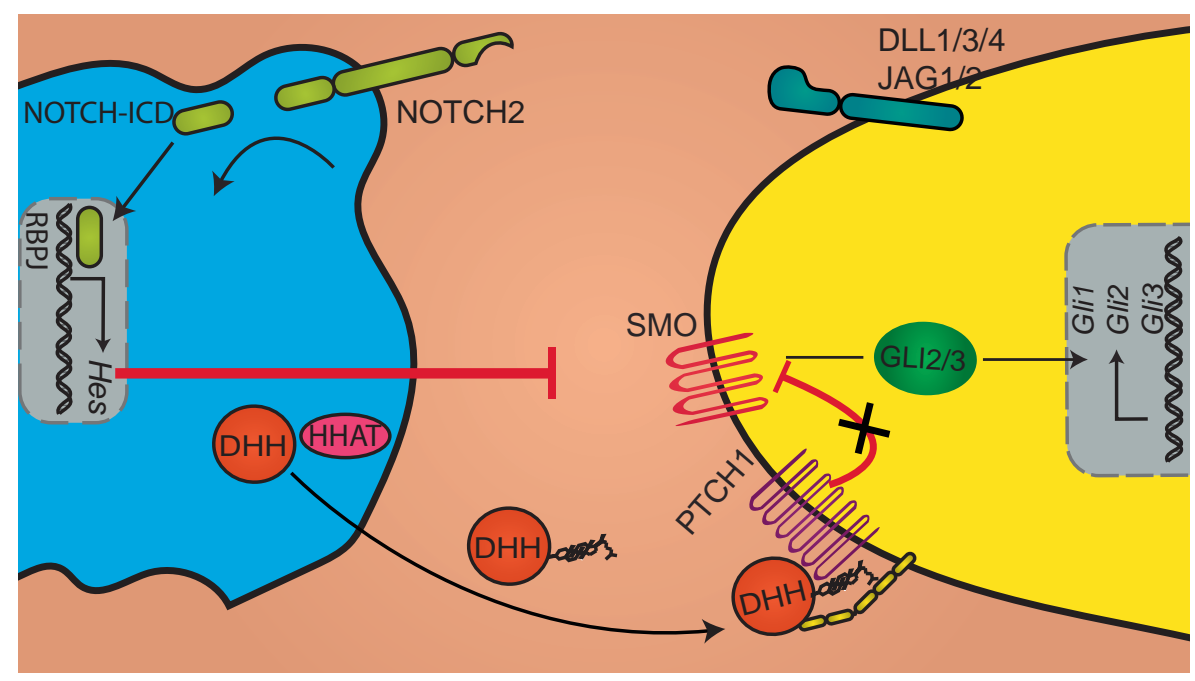

Fig. 2. Signaling pathways involved in Leydig cell differentiation. The pathway shown to be both necessary and sufficient to drive Leydig cell (yellow cell) differentiation is the DHH pathway. To activate signaling, $\mathrm{DHH}$ first undergoes a series of post-translational modifications including palmitoylation by the acyltransferase HHAT. Once secreted from Sertoli cells (blue cell), the active ligand binds PTCH1, which then releases its inhibition of SMO, ultimately resulting in full-length GLI proteins being translocated into the nucleus where they act as transcriptional activators of

A second, more unusual, signaling pathway has been identified that helps to maintain Sox9 expression in the developing testis [Adams and McLaren, 2002]. This regulatory loop involves SOX9 initiating a positive feedback loop via the direct transcriptional activation of Ptgds (prostaglandin D synthase) [Wilhelm et al., 2005], which produces $\mathrm{PGD}_{2}$ (prostaglandin $\mathrm{D}_{2}$ ). $\mathrm{PGD}_{2}$, via binding to its DP receptor, initiates an intracellular cascade including the activation of PKA (cAMP-dependent protein kinase A), which phosphorylates the SOX9 protein, leading to its nuclear translocation [Malki et al., 2005; Moniot et al., 2009]. In the nucleus, SOX9 then binds to its promoter to maintain its own expression (fig. 1C) [Sekido and Lovell-Badge, 2008]. Accordingly, Ptgds transcription is abolished in Sox9-null Sertoli cells, and Ptgds knockout testes have reduced Sox9 mRNA levels, abnormal SOX9 protein localization, and therefore delayed testis cord formation at early stages [Moniot et al., 2009]. However, at later stages testis cord structure appeared normal, demonstrating that the Sox9/Ptgds regulatory loop represents only a secondary mechanism to maintain Sox9 expression. hedgehog target genes. The second pathway implicated in Leydig cell differentiation is NOTCH signaling with activation of the pathway inhibiting recruitment of Leydig cells from undifferentiated progenitor cells. Binding of the ligands DLL1, 3 , and 4 as well as JAG1 and 2 to the NOTCH receptor on neighboring cells initiates proteolytic cleavage, releasing the intracellular domain, NOTCH-ICD, which translocates to the nucleus, binds RBPJ, and regulates target genes such as Hes 1 that ultimately inhibits differentiation of Leydig cells.

\section{Sertoli Cells Are the Control Centers of Testis Differentiation}

While Sry expression is transient, Sox 9 expression in Sertoli cells continues throughout life. Sertoli cells are the first to differentiate and are necessary to instruct other precursor cells to differentiate into testis-specific cell types, including the differentiation of PM and fetal Leydig cells, the prevention of entry into meiosis of germ cells in the testis, and the degradation of the Müllerian duct [Svingen and Koopman, 2013].

Leydig cells differentiate at around $12.5 \mathrm{dpc}$ in mouse testes and 8-9 weeks of gestation in humans [Habert et al., 2001] and increase in number at least 2-fold during fetal development. However, this increase in Leydig cell number is not due to proliferation [Byskov, 1986; Kerr and Knell, 1988; Migrenne et al., 2001] but is most likely the result of new recruitment from progenitor cells [Orth, 1982] driven by 2 signaling pathways; $\mathrm{DHH}$ as well as NOTCH signaling (fig. 2) in vasculature-associated cells in the interstitium [Tang et al., 2008]. A third pathway has been implicated with the ligand PDGFA (platelet-derived growth factor alpha) expressed in Sertoli cells and its receptor PDGFR $\alpha$ present on interstitial cells [Brennan et 
al., 2003]. Knockout of Pdgfra in the testis results in impaired fetal Leydig cell differentiation [Brennan et al., 2003]. These mice, however, also exhibit a reduction in Sertoli cell proliferation and mesonephric cell migration [Brennan et al., 2003], suggesting that the Leydig cell phenotype might not be a direct but a secondary effect.

The pathway that has been shown to be both necessary and sufficient to drive Leydig cell differentiation is the DHH pathway [Clark et al., 2000; Pierucci-Alves et al., 2001; Yao and Capel, 2002; Yao et al., 2002; Barsoum et al., 2009]. Detailed description of the HH signaling pathway can be found elsewhere [for example Varjosalo and Taipale, 2008; Hui and Angers, 2011; Robbins et al., 2012; Briscoe and Therond, 2013]. We will focus on the steps and molecules shown to be important for testis differentiation. To activate signaling through this pathway, the hedgehog ligand itself has to be processed to be fully active. After translation and removal of the signal sequence, the $\mathrm{HH}$ protein is cleaved into a C-terminal domain without signaling activity and an $\mathrm{N}$-terminal domain that is linked to cholesterol at its C-terminus [Porter et al., 1996]. This cholesterol-bound protein part is further processed by palmitoylation at its $\mathrm{N}$-terminus by the acyltransferase HHAT (hedgehog acyltransferase) for full activity (fig. 2) [Chamoun et al., 2001; Lee and Treisman, 2001]. This step has been shown to be crucial for Leydig cell differentiation, as mutations in the Hhat gene in mouse and human result in testicular dysgenesis with impaired testis cord formation and a loss of Leydig cell differentiation [Callier et al., 2014]. Subsequent binding of $\mathrm{HH}$ to its 12pass transmembrane protein receptor PTCH1 (patched 1) releases $\mathrm{PTCH} 1$ inhibition of the 7-pass transmembrane protein SMO (smoothened), resulting in pathway activation through the effector transcription factors of the GLI-Kruppel family, enabling transcription of hedgehog target genes (fig. 2).

While different hedgehog ligands are important throughout development, the main hedgehog ligand involved in the developing gonads is $\mathrm{DHH}$. DHH is expressed in Sertoli cells, while expression of PTCH1 is found on the surface of interstitial cells of the developing testis, including PM cells, Leydig cells, and endothelial cells [Bitgood et al., 1996; Clark et al., 2000]. While the phenotype of Dhh-null mice is variable depending on the genetic background, these mice typically show defective testis organization including abnormal development of PM cells, the absence of a basal lamina surrounding the testis cords, severely defective differentiation of fetal and adult Leydig cells and, subsequently, impaired spermatogenesis [Bitgood et al., 1996; Clark et al., 2000; Pierucci-

Signaling during Gonad Development
Alves et al., 2001; Yao and Capel, 2002; Yao et al., 2002]. This phenotype is largely consistent with $46, \mathrm{XY}$ partial or complete gonadal dysgenesis observed in human patients with mutations in $D H H$ [Umehara et al., 2000; Canto et al., 2004, 2005]. In contrast, mutation of the DHH receptor PTCH1 results in constitutive activation of the pathway [Ingham et al., 1991]. Mice homozygous for Ptch1 null mutations die between 9 and $10.5 \mathrm{dpc}$ during embryogenesis [Goodrich et al., 1997], too early to investigate a gonadal phenotype. However, similar to the null mutation of Ptch1, knockout of Smo in mice also results in the activation of the pathway. Conditional ablation of this gene in SF1-positive, somatic cells of embryonic mouse gonads resulted in the differentiation of functional fetal Leydig cells in the developing ovary [Barsoum et al., 2009], demonstrating that the $\mathrm{HH}$ pathway is not only necessary but also sufficient for Leydig cell differentiation.

Interestingly, in recent years it became obvious that in vertebrates a number of signaling pathways, and specifically hedgehog signaling, take place within the primary cilia of cells [Christensen et al., 2012; Clement et al., 2013; Oh and Katsanis, 2013; Mukhopadhyay and Rohatgi, 2014]. These microtubule-based organelles can be found on most vertebrate cell types [Satir and Christensen, 2007]. Primary cilia have sensory roles but, more importantly, also function as signaling centers on the cell surface. The formation, maintenance, and function of the primary cilium depends on intraflagellar transport (IFT) associated with 2 protein complexes, IFTA, which is required for retrograde (from tip to base) transport, and IFTB that is essential for anterograde (from base to tip) transport [Pedersen et al., 2008]. Defects in cilia formation due to mutations in IFT proteins lead to pleiotropic disorders in human collectively referred to as ciliopathies that display some aspects of mis-regulated $\mathrm{HH}$ signaling [Tobin and Beales, 2009; Toriello and Parisi, 2009]. Some of these syndromes such as the Bardet-Biedl syndrome are also often associated with hypoplastic testes [Green et al., 1989; Forsythe and Beales, 2013], which could be due to the role of $\mathrm{HH}$ signaling in Leydig cell differentiation. Accordingly, primary cilia are present on interstitial cells including Leydig and PM cells in mouse and human testis [Wainwright et al., 2014; Nygaard et al., 2015]. However, a hypomorphic mutation of the IFTA gene $W d r 19$ (also called Ift144) did not display a Leydig cell phenotype but instead resulted in hyperplastic gonads in both XX and $\mathrm{XY}$ embryos due to an extension of the embryo trunk [Wainwright et al., 2014]. It would be important to investigate the gonadal phenotype of other mouse models of 
ciliopathies [Norris and Grimes, 2012] to establish the function of these organelles and the role they play in $\mathrm{HH}$ signaling during gonad differentiation.

While $\mathrm{HH}$ signaling is required for Leydig cell differentiation, activation of the Notch pathway inhibits the recruitment of Leydig cells from undifferentiated progenitor cells (fig. 2) [Tang et al., 2008]. Mammals have $4 \mathrm{NOTCH}$ receptors, NOTCH1-4, and 5 canonical NOTCH ligands, DLL1 (Delta like 1), 3 and 4 and JAG1 (Jagged 1) and 2, that are all structurally related, singlepass transmembrane proteins [Artavanis-Tsakonas et al., 1999; D'Souza et al., 2008]. Binding of the receptor to the ligand on a neighboring cell initiates proteolytic cleavage to release the intracellular domain, NOTCH-ICD, which translocates into the nucleus, binds to RBPJ (recombination signal binding protein for immunoglobulin kappa J region), and regulates downstream target genes such as members of the Hes (hairy and enhancer of split) family [De Strooper et al., 1999; Tani et al., 2001; Gordon et al., 2008; Tien et al., 2009]. In developing mouse testes, Notch1 and Notch 4 are expressed in endothelial cells of the coelomic vessel [Brennan et al., 2002; Tang et al., 2008], whereas Notch2 is expressed in Sertoli cells at early stages before the expression shifts to interstitial cells where it is co-expressed with Notch 3 from $13.5 \mathrm{dpc}$ [Tang et al., 2008]. Inhibition of NOTCH signaling by blocking the proteolytic cleavage led to an increase in Leydig cell numbers, whereas constitutive activation reduced Leydig cell numbers [Tang et al., 2008], showing that NOTCH signaling restricts the number of cells that are recruited from progenitor cells to differentiate into Leydig cells (fig. 2).

In contrast to Leydig cells, which do not actively proliferate and increase in number through new recruitment from progenitor cells, Sertoli cells undergo 2 phases of proliferation; first, at the early stages to generate sufficient pre-Sertoli cells for testis determination and secondly to elongate the testis cords into highly coiled structures, which will eventually form the seminiferous tubules [Orth, 1982; Sharpe et al., 2003]. The first phase of proliferation is, as mentioned above, mainly driven by FGF9 [Willerton et al., 2004]. In contrast, proper Sertoli cell proliferation and testis cord expansion from $15.5 \mathrm{dpc}$ depends on Inhba (inhibin beta-A), expressed and secreted from Leydig cells [Archambeault and Yao, 2010]. Inhba encodes activin $\beta A$, which is a member of the TGF (transforming growth factor) superfamily.

The TGF superfamily of growth factors comprises more than 30 ligands in mammals, including TGF $\beta 1-3$, BMPs (bone morphogenetic proteins), activin A and B, NODAL, GDFs (growth differentiation factors), and AMH (anti-
Müllerian hormone). The receptors in these signaling pathways are single-pass transmembrane proteins with an intracellular serine-threonine kinase domain. The ligands bind as homo- or heterodimers to their respective type II receptor, initiating complex formation with the type I receptor and activating the intracellular signal transduction by SMADs [Shi and Massague, 2003; Itman et al., 2006]. Receptor binding of TGF $\beta$ isoforms, activin, and NODAL results in the phosphorylation SMAD2 and 3, while receptor binding of BMPs, GDFs, and AMH leads to phosphorylation of SMAD1, 5, and 8. These receptor-regulated SMADs then form a heterotrimeric complex with the common mediator SMAD4 and translocate into the nucleus to regulate gene expression by direct DNA binding or through the interaction with other transcription factors [Wakefield and Hill, 2013; Weiss and Attisano, 2013]. Irrespective of the binding ligand or receptor combinations used for signaling, SMAD phosphorylation, SMAD-complex formation, nuclear accumulation, and transcriptional regulation are central to effective signaling for all members within the TGF $\beta$ superfamily of growth factors. SMAD nuclear accumulation and transcriptional activity is further regulated by post-translational modifications such as phosphorylation by ERK/MAPK, GSK3 $\beta$ and CDKs, thus SMAD proteins serve as a possible mediator in the integration of several signaling pathways.

In addition to Inhba, also the founding members of the TGF superfamily, TGF $\beta 1-3$, are expressed in fetal testes with TGF $\beta 1$ expression in Sertoli cells, TGF $\beta 2$ in both Sertoli and Leydig cells, and TGF $\beta 3$ expressed in PM and germ cells [Memon et al., 2008]. While compensatory mechanisms between the TGF $\beta$ ligands obscure the elucidation of a role for single members of this family in testis development, loss of the TGF $\beta$ receptor TGFBR3 leads to abnormal testis cord structure and compromised fetal Leydig cell function, implicating this signaling pathway in testis differentiation [Sarraj et al., 2010]. This was further confirmed by blocking the 3 receptors ACVR1B (activin A receptor type 1B, also called ALK4), TGFBR1 (transforming growth factor beta receptor 1, also called ALK5), and ACVR1C (activin A receptor type 1C, also called ALK7) in ex vivo gonad culture using a potent inhibitor, thereby preventing testis cord formation [Miles et al., 2013].

\section{Signaling Pathways Driving Ovarian Differentiation}

In the absence of a functional SRY protein, Sox9 expression is not upregulated and the ovarian program of gene expression will prevail. In the fetal ovary this is 
mainly driven by one signaling pathway, the $\mathrm{WNT} / \beta$ catenin pathway activated by RSPO1 and WNT4, as well as the transcriptional regulator FOXL2.

Wnt4 and Rspo1 are initially expressed in somatic cells of the genital ridges of both XX and XY individuals before being downregulated in the developing testis and maintained in the ovary from around $12.5 \mathrm{dpc}$ in the mouse [Vainio et al., 1999; Parma et al., 2006]. Both WNT4 and RSPO1 signal through the canonical WNT pathway, causing the stabilization and nuclear translocation of $\beta$-catenin. Accordingly, ectopic expression of constitutively active $\beta$-catenin in the developing testis leads to male-to-female sex reversal [Maatouk et al., 2008]. In contrast, the deletion of either Wnt4 or Rspo1 only results in partial female-to-male sex reversal associated with the appearance of testis-specific vasculature and ectopic androgen-producing cells, as well as a reduction in germ cell number [Vainio et al., 1999; Jeays-Ward et al., 2003; Chassot et al., 2008; Tomizuka et al., 2008]. In the absence of WNT4, ovarian markers such as Bmp2 and Fst (follistatin), which encode TGF $\beta$ superfamily ligands, are not expressed [Yao et al., 2004]. Indeed, FST acts downstream of Wnt4 to inhibit the formation of testis-specific vasculature in the ovary while simultaneously maintaining the survival of germ cells [Yao et al., 2004]. Similar to the mouse phenotype, heterozygous WNT4 mutations in humans lead to reproductive phenotypes in females [Biason-Lauber et al., 2004, 2007; Philibert et al., 2008, 2011], and XX patients with heterozygous mutation in RSPO1 display female-to-male sex reversal associated with the skin disorder palmoplantar hyperkeratosis with squamous cell carcinoma [Parma et al., 2006].

Interestingly, there is a difference in the cause for the reduced germ cell numbers between Wnt4 and Rspo1null ovaries. The loss of Rspo1 results in a decrease in germ cell proliferation, which is already evident at 12.5 dpc [Chassot et al., 2012]. In contrast in Wnt4-null ovaries, germ cell proliferation is unaffected but apoptosis is increased [Yao et al., 2004]. This indicates that these 2 signaling molecules, although functioning through the same mediator $\beta$-catenin, do not have completely overlapping functions during ovarian development.

A loss of germ cells was once thought to cause transdifferentiation of granulosa cells into Sertoli-like cells [Burgoyne et al., 1988; McLaren, 1991; Guigon and Magre, 2006]. Accordingly, gonads in the Wnt4- and Rspo1-null mice not only show a reduction in germ cells but also an upregulation of the Sertoli cell marker AMH at later stages during fetal development [Vainio et al., 1999; Chassot et al., 2008]. However, 2 lines of evidence speak against this hypothesis. First, it has been demonstrated recently that a loss of germ cells is not sufficient to cause trans-differentiation of granulosa cells into Sertoli cells [Uhlenhaut et al., 2009]. And secondly, it appears that most of the AMH expression in the Wnt4- and Rspo1-mutant ovaries [Vainio et al., 1999; Chassot et al., 2008] is not a sign of granulosa cell trans-differentiation but rather precocious maturation, as demonstrated by the lack of other Sertoli cell markers such as DMRT1 and continuous expression of granulosa cell markers such as activated BMP signaling [Maatouk et al., 2013]. This premature differentiation of granulosa cells appears to be independent of the loss of germ cells; however, the presence of germ cells at earlier stages is required [Maatouk et al., 2013]. Only after birth do granulosa cells in these mutant ovaries start to express SOX9 and display signs of transdifferentiation [Maatouk et al., 2013].

\section{Cross-Talk between the Testicular and Ovarian Pathway of Gene Expression}

Gonadal identity is not, as believed for a long time, fixed to one sex once differentiation has taken place, but rather the sexual phenotype of cells must be actively maintained, while concurrently repressing that of the other sex. This ultimately results in a paradigm wherein genes and factors expressed in a testis antagonize those expressed in an ovary and vice versa in order to maintain gonadal identity.

Antagonistic relationships in the fetal gonad involve FGF9 signaling repressing the RSPO1/WNT/ $\beta$-catenin signaling pathway and vice versa [Kim et al., 2006]. Knockout of Fgf 9 or its receptor Fgfr 2 resulted in the upregulation of Wnt4 expression and testis-to-ovary sex reversal [Colvin et al., 2001; Kim et al., 2006, 2007; BagheriFam et al., 2008; Siggers et al., 2014]. Similarly, partial ovary-to-testis sex reversal was observed when Wnt4 [Vainio et al., 1999; Jeays-Ward et al., 2003], Rspo1 [Chassot et al., 2008; Tomizuka et al., 2008], or $\beta$-catenin [Manuylov et al., 2008; Liu et al., 2009] was ablated.

Interestingly, double knockout studies involving the combination of male- and female-determining pathways such as Wnt4 and Fgf9 or Wnt4 and Fgfr2 [Jameson et al., 2012], Rspo1 and Sox9 [Lavery et al., 2012], or Ctnnb1 ( $\beta$-catenin) and Sox9 [Nicol and Yao, 2015] rescued the male-to-female sex reversal phenotype in XY gonads of the single knockout of Sox9, Fgf9, or Fgfr2. In contrast in $\mathrm{XX}$ gonads, the partial female-to-male sex reversal of the single knockout of Wnt4, Rspo1, or Ctnnb1 was not res- 
cued in the double-knockout gonads. Hence, both XY and XX gonads display testicular features, although XY were more masculinized than XX double knockout gonads. This suggests that the expression of testis-specific genes other than Sox9 and Fgf9 requires the repression of the $\beta$-catenin pathway rather than the direct activation by SOX9. A possible explanation lies in the redundancy that exists among SOX transcription factors. For example, SRY and SOX9 [Li et al., 2014], as well as SOX9, SOX8, and SOX10 [Schepers et al., 2003; Polanco et al., 2010] have been shown to activate similar target genes. Accordingly, the masculinization of Sox $9 / \beta$-catenin double knockout XY gonads was associated with the expression of Sry and Sox8 [Nicol and Yao, 2015]. In contrast, for the expression of ovarian-specific genes the activation by the $\beta$-catenin pathway is absolutely essential.

Surprisingly, sexual identity of gonadal cells not only has to be sustained during fetal development but also postnatally. This maintenance of adult sexual identity is mediated by 2 transcription factors, testis-expressed DMRT1 (doublesex and mab-3 related transcription factor 1) and ovary-expressed FOXL2 in cooperation with ESR1 and 2 (oestrogen receptors 1 and 2) [Uhlenhaut et al., 2009; Matson et al., 2011; Minkina et al., 2014]. Inducible deletion of Foxl2 in adult XX mouse ovaries leads to immediate upregulation of Sox 9 and, subsequently, reprogramming of granulosa and theca cells into Sertoli and Leydig-like cells [Uhlenhaut et al., 2009]. FOXL2 and ESR 1 and 2 have been shown to directly bind to the gonad enhancer of Sox9, called TESCO, to repress Sox9 transcription [Uhlenhaut et al., 2009]. Conversely, DMRT1 binds to a number of regulatory regions to repress ovarian-promoting genes and to activate testis-promoting genes [Minkina et al., 2014]. Hence, deletion of Dmrt1 in adult testes results in the activation of Foxl2 and the downregulation of Sox 9 expression, leading to trans-differentiation of Sertoli cells into granulosa-like cells [Matson et al., 2011].

\section{Signaling Pathways Driving Germ Cell Development}

Like the gonads themselves, the gametes of both males and females arise from a common precursor. PGCs arise as a result of inductive signaling from both the extraembryonic ectoderm and the visceral endoderm during gastrulation [Lawson et al., 1999]. As a result, PGCs are specified independently of the 3 germ layers at approximately $7.0 \mathrm{dpc}$ in mice and during the third week of gestation in humans [Chiquoine, 1954; Ginsburg et al., 1990]. This specification is induced by BMP4 and BMP8B, secreted by the extraembryonic ectoderm, and BMP2 produced by the visceral endoderm [Lawson et al., 1999; Ying et al., 2000; Ying and Zhao, 2001]. BMP4 is sufficient to induce PGC specification and as BMP2, although less efficient [Ohinata et al., 2009]. In contrast, BMP8B does not have a direct effect on PGCs but is necessary for PGC specification if the visceral endoderm is present [Ohinata et al., 2009], suggesting that it counteracts negative signals. BMPs function through the ALK2 receptor to induce phosphorylation and activation of SMAD1 and SMAD5 [De Sousa Lopes et al., 2004]. Accordingly, heterozygous mutations in any of the genes encoding these signaling molecules, i.e. Bmp4, Bmp2, Bmp8b, Alk2, Smad1, or $S m a d 5$, result in a reduced PGC number, while null mutations result in a complete loss of PGCs [Chang and Matzuk, 2001; Tremblay et al., 2001; Hayashi et al., 2002; Aubin et al., 2004; Chu et al., 2004; De Sousa Lopes et al., 2004; Yamaji et al., 2008; Ohinata et al., 2009]. Activation of the BMP signaling pathway results in the expression of 2 key genes, $\operatorname{Prdm} 1$ (PR domain containing 1, also called Blimp1 for B-lymphocyte-induced maturation protein 1) and Prdm 14 (PR domain-containing protein 14). PRDM1 is a potent transcriptional repressor of the somatic cell fate within PGCs, while Prdm14 acts as a transcriptional regulator, critical for germ cell pluripotency and epigenetic reprogramming [Ohinata et al., 2005; Vincent et al., 2005; Yabuta et al., 2006; Kurimoto et al., 2008; Yamaji et al., 2008]. In addition to BMP, WNT signaling is also essential for germ cell fate at this time, with Wnt3 mutants exhibiting a loss of both $\mathrm{Prdm} 1$ and 14 expression [Ohinata et al., 2009].

Following specification, PGCs migrate, driven by morphogenic gradients, towards the developing gonadal ridges [Fujimoto et al., 1977]. These migrating germ cells express 2 FGF receptors, FGFR1 and FGFR2. Signaling through these receptors by FGF2 and FGF7 via the MAP kinase pathways affects germ cell motility and number [Takeuchi et al., 2005]. In addition, the WNT and BMP pathways have also been implicated in the migration of PGCs. Wnt5a-null embryos of both sexes exhibit a significant reduction in the number of primordial germ cells colonizing the gonads due to both abnormal germ cell migration and an increase in apoptosis [Laird et al., 2011; Chawengsaksophak et al., 2012]. Similarly, a reduction in BMP signaling via the ablation of the receptor BMPR1A results in a reduction in migratory germ cells [Dudley et al., 2010].

Upon colonization of the gonads between 10.0 and $11.0 \mathrm{dpc}$, PGCs undergo rapid proliferation, which is 
Fig. 3. Signaling pathways driving germ cell development. A During ovary differentiation, retinoic acid (RA, purple) is produced by ALDH1A2 in the mesonephros, diffuses into the ovary where it binds to its receptor RAR and induces expression of Stra8 in ovarian germ cells, which is necessary for the entry into meiosis. B In contrast, during testis differentiation, while also the XY mesonephros produces RA, Sertoli cells express the RA-degrading enzyme CYP26B1, preventing germ cells to enter meiosis at this stage. Instead, germ cells exit the cell cycle and arrest in a quiescent state. Testicular germ cells are characterized by the expression of Nanos2, which is induced by 2 signaling pathways. FGF9 signaling within somatic (blue) and germ (green) cells leads to the upregulation of 2 TGF $\beta$ superfamily members, InhbA and Nodal, respectively. ActivinA and NODAL then signal by binding the type II receptors ALK4 and ALK7 in conjunction with the co-receptor TDGF1, which initiates complex formation with ALK5. This ultimately results in phosphorylation of SMAD2, which binds to SMAD4 and translocates into the nucleus to activate Nanos 2 expression. Additionally, NODAL signaling leads to the upregulation of Nodal itself as well as Lefty 1 and 2, which act as dose-dependent feedback inhibitors of the pathway.

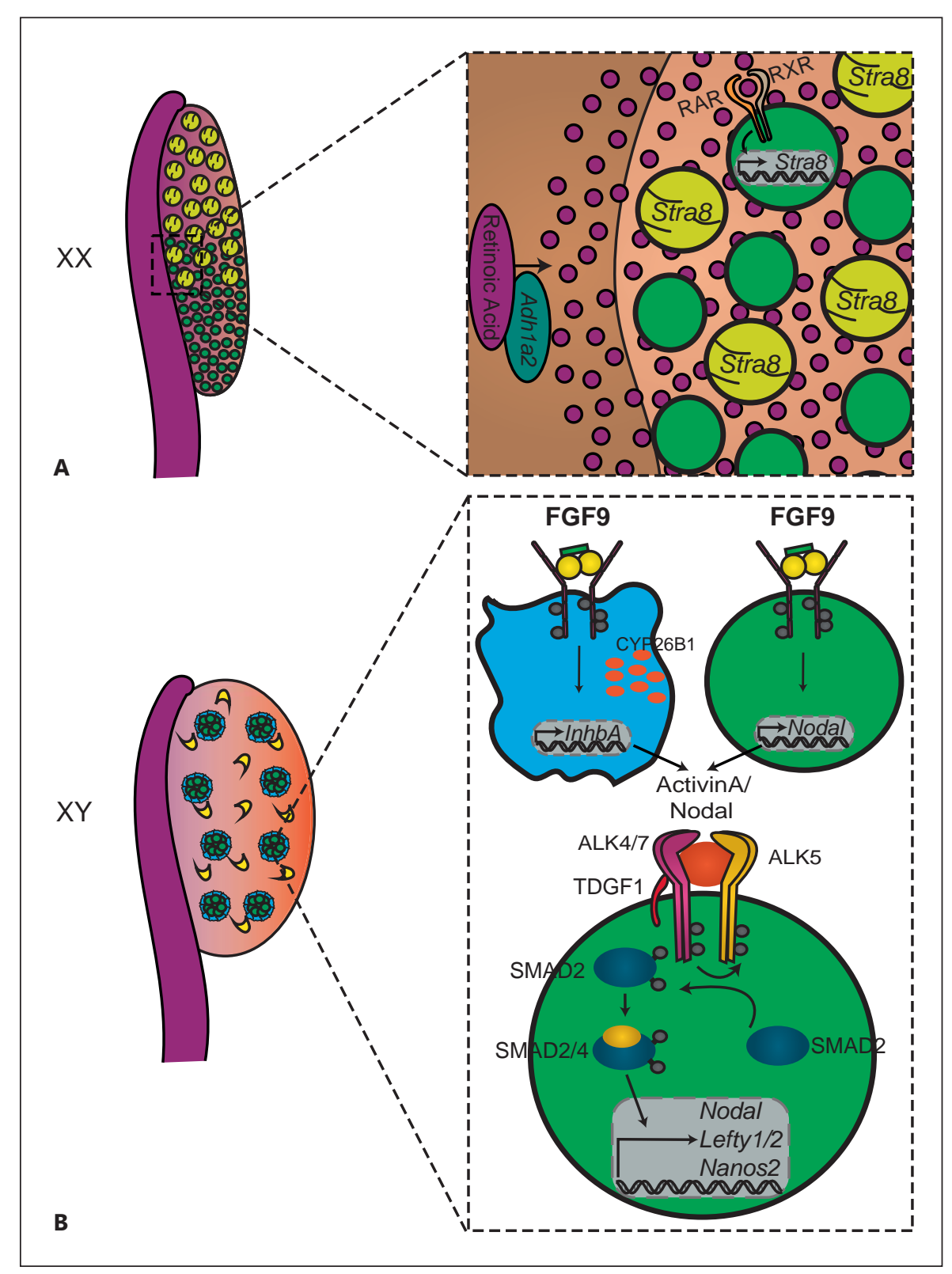

transiently reliant on BMP7 signaling [Ross et al., 2007]. Further, upon entering the gonads, PGCs begin to express FGF4 and FGF8 which then act in an autocrine manner to maintain proliferation of the germ cells [Kawase et al., 2004]. This proliferation of PGCs continues until 13.5 $\mathrm{dpc}$ in mice and 11-12 weeks of gestation in humans, when a stark difference in the morphology of germ cells within the testis and ovary is observed. Germ cells fated to the male lineage enter mitotic arrest, while those destined to become oogonia enter the first meiotic prophase (fig. 3) [McLaren and Southee, 1997].

Signaling during Gonad Development
While the timing of germ cell entry into meiosis differs between the sexes, Stra8 (stimulated by retinoic acid gene 8 ) is important in the transition from mitosis to meiosis in both sexes, first expressed in the embryonic ovary at approximately $12.5 \mathrm{dpc}$ [Menke et al., 2003] and postnatally in the developing testis. Expression of Stra 8 is stimulated by the presence of an active derivative of vitamin A, retinoic acid (RA), catalyzed by the enzyme ALDH1A2 (aldehyde dehydrogenase family 1, subfamily A2) (fig. 3) [Bowles et al., 2006; Koubova et al., 2006]. Entry into meiosis differs slightly between species, with mouse germ cells 
entering meiosis in an anterior-to-posterior wave due to RA production by the mesonephros [Menke et al., 2003; Bullejos and Koopman, 2004; Bowles et al., 2006; Koubova et al., 2006], while human germ cells enter meiosis radially, beginning in the medulla, due to RA production by the ovary itself [Childs et al., 2011]. While RA is also produced by the mesonephros adjacent to a mouse testis, expression of the RA-degrading enzyme CYP26B1 (cytochrome P450, family 26, subfamily b, polypeptide 1) by Sertoli cells prevents meiotic entry of germ cells in the embryonic testis (fig. 3) [Bowles et al., 2006; Koubova et al., 2006].

Following retinoid signaling, germ cells in an ovary progress through the stages of the first meiotic prophase before arresting at the diplotene stage [Borum, 1961; Speed, 1982]. Meiosis resumes upon maturation into primordial follicles, a process dependent on NOTCH signaling [Trombly et al., 2009; Vanorny et al., 2014], before being completed at the time of fertilization.

In contrast to germ cells in the developing ovary, germ cells in a testis exit the mitotic cell cycle at the G1 phase to remain in a quiescent state (G0) until shortly after birth when mitosis recommences before eventually entering meiosis [McLaren and Buehr, 1990; Western et al., 2008; Spiller et al., 2009]. A distinctive feature of testicular germ cells at this time is the expression of Pou $5 f 1$ (POU domain, class 5 , transcription factor 1 , also called OCT3/4), which is otherwise downregulated upon entry into meiosis. TGF $\beta$ signaling may regulate germ cell quiescence at this time in addition to its role as an anti-proliferative and anti-apoptotic factor for primordial germ cells [Godin and Wylie, 1991; Richards et al., 1999; Moreno et al., 2010]. In addition, inhibition of p38 MAP kinases resulted in an upregulation of the meiotic markers Stra 8 and Sycp3 [Ewen et al., 2010], suggesting that this signaling pathway also plays a role. In support of this, MAPK pathways are activated by FGF9, which has been shown to promote the differentiation of PGCs towards spermatogenesis (fig. 3), while promoting survival of germ cells within the fetal testis independent of Sertoli cells [Colvin et al., 2001; DiNapoli et al., 2006]. This occurs as a result of the upregulation of Nanos2, a hallmark of testicular primordial germ cells [Barrios et al., 2009]. Loss of Nanos2 in testicular germ cells leads to a complete loss of spermatogonia [Tsuda et al., 2003], while ectopic expression of the gene in ovarian germ cells results in male-like germ cell differentiation through the suppression of Stra8 expression [Suzuki and Saga, 2008].

Induction of Nanos2 expression by FGF9 occurs through the upregulation of 2 TGF $\beta$ superfamily members: NODAL, produced by germ cells, and Inhba, pro- duced by testicular somatic cells (fig. 3). NODAL signaling has been shown to be active in XY but not in XX PGCs at the time of sex determination [Souquet et al., 2012; Spiller et al., 2012] and signals by binding to activin receptors in the presence of the co-receptor TDGF1 (teratocarcinoma-derived growth factor 1, also called Cripto). Ultimately, this leads to upregulation of Nodal itself as well as upregulation of 2 other TGF $\beta$ molecules, LEFTY (left right determination factor) 1 and 2, both of which act as dose-dependent feedback inhibitors of the pathway.

NODAL and INHBA work redundantly and have dual functions in promoting the male germ cell fate through the upregulation of Nanos 2 and suppression of meiosis. Additionally, they act to prevent differentiation of female somatic cells within the developing testis [Souquet et al., 2012; Wu et al., 2013]. Signaling within these pathways occurs through the receptors ALK4 and ALK7 [Miles et al., 2013] and the SMAD2 pathway to promote male differentiation in a RAindependent manner [Wu et al., 2015].

\section{Conclusions}

While a lot of work has gone into elucidating the role of transcription factors in driving the differentiation of specific cell types within the fetal testis and ovary, their activity is ultimately regulated by signal transduction pathways that coordinate the development of the gonads as a whole. Roles for many of these pathways in gonadogenesis have been identified through mutation analysis in human and mouse as well as inhibitor studies using ex vivo gonad culture approaches; however, we are far from completely understanding their function. Moreover, cross-talk is known to exist between different signal transduction cascades and, as such, the cumulative effects of these pathways may greatly alter the response to signaldependent cues. Thus, while no such examples have been elucidated to date, it would be interesting to further analyze the integration and divergence of these pathways within the developing gonad to better understand the complex molecular interplay dictating gonadogenesis and, consequently, fertility.

\section{Acknowledgements}

We thank Dr. Patrick Western (Hudson Institute, Clayton, Vic., Australia) for critical reading of the manuscript. This work was supported by a research grant from the Australian Research Council (DP150101448). D.W. is a Future Fellow of the ARC (FT110100327). 


\section{Statement of Ethics}

The authors have no ethical conflicts to disclose.

\section{Disclosure Statement}

The authors have no conflicts of interest to declare.

\section{References}

- Aberle H, Bauer A, Stappert J, Kispert A, Kemler $\mathrm{R}$ : Beta-catenin is a target for the ubiquitinproteasome pathway. EMBO J 16:3797-3804 (1997).

Adams IR, McLaren A: Sexually dimorphic development of mouse primordial germ cells: switching from oogenesis to spermatogenesis. Development 129:1155-1164 (2002).

- Alarid ET, Rubin JS, Young P, Chedid M, Ron D, et al: Keratinocyte growth factor functions in epithelial induction during seminal vesicle development. Proc Natl Acad Sci USA 91: 1074-1078 (1994).

-Anderson R, Copeland TK, Scholer H, Heasman J, Wylie C: The onset of germ cell migration in the mouse embryo. Mech Dev 91:61-68 (2000).

- Archambeault DR, Yao HH: Activin A, a product of fetal Leydig cells, is a unique paracrine regulator of Sertoli cell proliferation and fetal testis cord expansion. Proc Natl Acad Sci USA 107:10526-10531 (2010).

-Artavanis-Tsakonas S, Rand MD, Lake RJ: Notch signaling: cell fate control and signal integration in development. Science 284:770-776 (1999).

-Aubin J, Davy A, Soriano P: In vivo convergence of BMP and MAPK signaling pathways: impact of differential Smad1 phosphorylation on development and homeostasis. Genes Dev 18:1482-1494 (2004).

Bagheri-Fam S, Sim H, Bernard P, Jayakody I, Taketo MM, et al: Loss of Fgfr2 leads to partial XY sex reversal. Dev Biol 314, 71-83 (2008).

Bagheri-Fam S, Ono M, Li L, Zhao L, Ryan J, et al: FGFR2 mutation in 46,XY sex reversal with craniosynostosis. Hum Mol Genet 24:66996710 (2015).

-Barrios F, Filipponi D, Pellegrini M, Paronetto MP, Di Siena S, et al: Opposing effects of retinoic acid and FGF9 on Nanos2 expression and meiotic entry of mouse germ cells. J Cell Sci 126:871-880 (2009).

Barsoum IB, Bingham NC, Parker KL, Jorgensen JS, Yao HH: Activation of the Hedgehog pathway in the mouse fetal ovary leads to ectopic appearance of fetal Leydig cells and female pseudohermaphroditism. Dev Biol 329:96103 (2009).

Beadling C, Johnson KW, Smith KA: Isolation of interleukin 2-induced immediate-early genes. Proc Natl Acad Sci USA 90:2719-2723 (1993).

-Biason-Lauber A, Konrad D, Navratil F, Schoenle EJ: A WNT4 mutation associated with Mullerian-duct regression and virilization in a 46,XX woman. The New England J Med 351: $792-798$ (2004).
Biason-Lauber A, De Filippo G, Konrad D, Scarano G, Nazzaro A, Schoenle EJ: WNT4 deficiency - a clinical phenotype distinct from the classic Mayer-Rokitansky-Kuster-Hauser syndrome: a case report. Hum Reprod 22: 224-229 (2007).

Bienz M, Clevers H: Armadillo/beta-catenin signals in the nucleus-proof beyond a reasonable doubt? Nat Cell Biol 5:179-182 (2003).

-Bitgood MJ, Shen L, McMahon AP: Sertoli cell signaling by desert hedgehog regulates the male germline. Curr Biol 6:298-304 (1996).

Bogani D, Siggers P, Brixey R, Warr N, Beddow S, et al: Loss of mitogen-activated protein kinase kinase kinase 4 (MAP3K4) reveals a requirement for MAPK signalling in mouse sex determination. PLoS Biol 7:e1000196 (2009).

Borum K: Oogenesis in the mouse. A study of the meiotic prophase. Exp Cell Res 24:495-507 (1961).

Bowles J, Schepers G, Koopman P: Phylogeny of the SOX family of developmental transcription factors based on sequence and structural indicators. Dev Biol 227:239-255 (2000).

Bowles J, Knight D, Smith C, Wilhelm D, Richman J, et al: Retinoid signaling determines germ cell fate in mice. Science 312:596-600 (2006).

Bradford ST, Wilhelm D, Bandiera R, Vidal V, Schedl A, Koopman P: A cell-autonomous role for WT1 in regulating Sry in vivo. Hum Mol Genet 18:3429-3438 (2009).

Brennan J, Karl J, Capel B: Divergent vascular mechanisms downstream of Sry establish the arterial system in the XY gonad. Dev Biol 244: 418-428 (2002).

Brennan J, Tilmann C, Capel B: PDGFR-alpha mediates testis cord organization and fetal Leydig cell development in the XY gonad. Genes Dev 17:800-810 (2003).

Briscoe J, Therond PP: The mechanisms of Hedgehog signalling and its roles in development and disease. Nature Rev Mol Cell Biol 14:416-429 (2013).

Bullejos M, Koopman P: Germ cells enter meiosis in a rostro-caudal wave during development of the mouse ovary. Mol Reprod Dev 68:422428 (2004).

Burgoyne PS, Buehr M, McLaren A: XY follicle cells in ovaries of XX-XY female mouse chimaeras. Development 104:683-688 (1988).

Byskov AG: Differentiation of mammalian embryonic gonad. Physiol Rev 66:71-117 (1986).

Callier P, Calvel P, Matevossian A, Makrythanasis $\mathrm{P}$, Bernard P, et al: Loss of function mutation in the palmitoyl-transferase HHAT leads to syndromic 46,XY disorder of sex development by impeding Hedgehog protein palmitoylation and signaling. PLoS Genet10: e1004340 (2014).

Canto P, Soderlund D, Reyes E, Mendez JP: Mutations in the desert hedgehog $(\mathrm{DHH})$ gene in patients with 46,XY complete pure gonadal dysgenesis. J Clin Endocrinol Metabol 89: 4480-4483 (2004).

Canto P, Vilchis F, Soderlund D, Reyes E, Mendez JP: A heterozygous mutation in the desert hedgehog gene in patients with mixed gonadal dysgenesis. Mol Hum Reprod 11:833-836 (2005)

Chamoun Z, Mann RK, Nellen D, von Kessler DP, Bellotto M, et al: Skinny hedgehog, an acyltransferase required for palmitoylation and activity of the hedgehog signal. Science 293: 2080-2084 (2001).

Chang H, Matzuk MM: Smad5 is required for mouse primordial germ cell development. Mech Dev104:61-67 (2001)

Chassot AA, Ranc F, Gregoire EP, Roepers-Gajadien HL, Taketo MM, et al: Activation of beta-catenin signaling by Rspol controls differentiation of the mammalian ovary. Hum Mol Genet 17:1264-1277 (2008).

Chassot AA, Bradford ST, Auguste A, Gregoire EP, Pailhoux E, et al: WNT4 and RSPO1 together are required for cell proliferation in the early mouse gonad. Development 139:44614472 (2012).

Chawengsaksophak K, Svingen T, Ng ET, Epp T, Spiller CM, et al: Loss of $W n t 5 a$ disrupts primordial germ cell migration and male sexual development in mice. Biol Reprod 86:1-12 (2012).

Childs AJ, Cowan G, Kinnell HL, Anderson RA, Saunders PT: Retinoic acid signalling and the control of meiotic entry in the human fetal gonad. PLoS One 6:e20249 (2011).

Chiquoine AD: The identification, origin, and migration of the primordial germ cells in the mouse embryo. Anat Rec 118:135-146 (1954).

Christensen ST, Clement CA, Satir P, Pedersen LB: Primary cilia and coordination of receptor tyrosine kinase (RTK) signalling. J Pathol 226:172-184 (2012).

Chu GC, Dunn NR, Anderson DC, Oxburgh L, Robertson EJ: Differential requirements for Smad4 in TGFbeta-dependent patterning of the early mouse embryo. Development 131: 3501-3512 (2004).

Clark AM, Garland KK, Russell LD: Desert hedgehog $(D h h)$ gene is required in the mouse testis for formation of adult-type Leydig cells and normal development of peritubular cells and seminiferous tubules. Biol Reprod 63: 1825-1838 (2000). 
Clement DL, Mally S, Stock C, Lethan M, Satir P, Geissler WM, Davis DL, Wu L, Bradshaw KD, et al: PDGFR-alpha signaling in the primary cilium regulates NHE1-dependent fibroblast migration via coordinated differential activity of MEK1/2-ERK1/2-p90RSK and AKT signaling pathways. J Cell Sci 126:953-965 (2013).

Clevers H, Nusse R: Wnt/beta-catenin signaling and disease. Cell 149:1192-1205 (2012).

Colvin JS, Green RP, Schmahl J, Capel B, Ornitz DM: Male-to-female sex reversal in mice lacking fibroblast growth factor 9. Cell 104:875889 (2001).

Combes AN, Wilhelm D, Davidson T, Dejana E, Harley V, et al: Endothelial cell migration directs testis cord formation. Dev Biol 326:112120 (2009).

Coveney D, Cool J, Oliver T, Capel B: Four-dimensional analysis of vascularization during primary development of an organ, the gonad. Proc Natl Acad Sci USA 105:7212-7217 (2008).

De Sousa Lopes SM, Roelen BA, Monteiro RM, Emmens R, Lin HY, et al: BMP signaling mediated by ALK2 in the visceral endoderm is necessary for the generation of primordial germ cells in the mouse embryo. Genes Dev 18:1838-1849 (2004).

De Strooper B, Annaert W, Cupers P, Saftig P, Craessaerts K, et al: A presenilin-1-dependent gamma-secretase-like protease mediates release of Notch intracellular domain. Nature 398:518-522 (1999).

DiNapoli L, Batchvarov J, Capel B: FGF9 promotes survival of germ cells in the fetal testis. Development 133:1519-1527 (2006).

D'Souza B, Miyamoto A, Weinmaster G: The many facets of Notch ligands. Oncogene 27: 5148-5167 (2008).

-Dudley B, Palumbo C, Nalepka J, Molyneaux K: BMP signaling controls formation of a primordial germ cell niche within the early genital ridges. Dev Biol 343:84-93 (2010).

-Ellis LC, Farr GC, Tesi RJ: Contractility of seminiferous tubules as related to sperm transport in the male. Syst Biol Reprod Med 6:283-294 (1981).

Epifano O, Dean J: Genetic control of early folliculogenesis in mice. Trends Endocrinol Metabol 13:169-173 (2002).

-Ewen K, Jackson A, Wilhelm D, Koopman P: A male-specific role for p38 mitogen-activated protein kinase in germ cell sex differentiation in mice. Biol Reprod 83:1005-1014 (2010).

Forsythe E, Beales PL: Bardet-Biedl syndrome. Eur J Hum Genet 21:8-13 (2013).

-Fujimoto T, Miyayama Y, Fuyuta M: The origin, migration and fine morphology of human primordial germ cells. Anat Rec 188:315-330 (1977).

- Gardner PJ, Holyoke EA: Fine structure of the seminiferous tubule of the swiss mouse. I. The limiting membrane, Sertoli cell, spermatogonia, and spermatocytes. Anat Rec 150:391404 (1964). Patel S, et al: Male pseudohermaphroditism caused by mutations of testicular 17 beta-hydroxysteroid dehydrogenase 3. Nat Genet 7: 34-39 (1994).

- Gierl MS, Gruhn WH, von Seggern A, Maltry N, Niehrs C: GADD45G functions in male sex determination by promoting p38 signaling and Sry expression. Dev Cell 23:1032-1042 (2012).

- Giese K, Amsterdam A, Grosschedl R: DNAbinding properties of the HMG domain of the lymphoid-specific transcriptional regulator LEF-1. Genes Dev 5:2567-2578 (1991).

Gilbert E, Del Gatto F, Champion-Arnaud P, Gesnel MC, Breathnach R: Control of BEK and K-SAM splice sites in alternative splicing of the fibroblast growth factor receptor 2 premRNA. Mol Cell Biol 13:5461-5468 (1993).

-Ginsburg M, Snow MH, McLaren A: Primordial germ cells in the mouse embryo during gastrulation. Development 110:521-528 (1990).

Godin I, Wylie CC: TGF-beta inhibits proliferation and has a chemotrophic effect on mouse primoridal germ cells in culture. Development 113:1451-1457 (1991).

-Goodrich LV, Milenkovic L, Higgins KM, Scott MP: Altered neural cell fates and medulloblastoma in mouse patched mutants. Science 277:1109-1113 (1997).

Gordon WR, Arnett KL, Blacklow SC: The molecular logic of Notch signaling - a structural and biochemical perspective. J Cell Sci 121: 3109-3119 (2008).

Gougeon A: Regulation of ovarian follicular development in primates: facts and hypotheses. Endocr Rev 17:121-155 (1996).

-Green JS, Parfrey PS, Harnett JD, Farid NR, Cramer BC, et al: The cardinal manifestations of Bardet-Biedl syndrome, a form of LaurenceMoon-Biedl syndrome. N Engl J Med 321: 1002-1009 (1989).

- Gubbay J, Collignon J, Koopman P, Capel B, Economou A, et al: A gene mapping to the sex-determining region of the mouse $\mathrm{Y}$ chromosome is a member of a novel family of embryonically expressed genes. Nature 346:245250 (1990).

Guigon CJ, Magre S: Contribution of germ cells to the differentiation and maturation of the ovary: insights from models of germ cell depletion. Biol Reprod 74:450-458 (2006).

Habert R, Lejeune H, Saez JM: Origin, differentiation and regulation of fetal and adult Leydig cells. Mol Cell Endocrinol 179:47-74 (2001).

-Hanley N, Hagan D, Clement-Jones M, Ball S, Strachan T, et al: $S R Y, S O X 9$, and DAX1 expression patterns during human sex determination and gonadal development. Mech Dev 91:403-407 (2000).

Hayashi K, Kobayashi T, Umino T, Goitsuka R, Matsui Y, Kitamura D: SMAD1 signaling is critical for initial commitment of germ cell lineage from mouse epiblast. Mech Dev 118: 99-109 (2002).
Hirshfield AN: Theca cells may be present at the outset of follicular growth. Biol Reprod 44: 1157-1162 (1991).

Hui CC, Angers S: GLI proteins in development and disease. Ann Rev Cell Dev Biol 27:513537 (2011).

Hummitzsch K, Irving-Rodgers HF, Hatzirodos N, Bonner W, Sabatier L, et al: A new model of development of the mammalian ovary and follicles. PLoS One 8:e55578 (2013).

Ingham PW, Taylor AM, Nakano Y: Role of the Drosophila patched gene in positional signalling. Nature 353:184-187 (1991).

Itman C, Mendis S, Barakat B, Loveland KL: All in the family: TGF-beta family action in testis development. Reproduction 132:233-246 (2006).

Jameson SA, Lin YT, Capel B: Testis development requires the repression of Wnt 4 by FGF signaling. Dev Biol 370:24-32 (2012).

Jeays-Ward K, Hoyle C, Brennan J, Dandonneau M, Alldus G, et al: Endothelial and steroidogenic cell migration are regulated by WNT4 in the developing mammalian gonad. Development 130:3663-3670 (2003).

Jeays-Ward K, Dandonneau M, Swain A: Wnt4 is required for proper male as well as female sexual development. Dev Biol 276:431-440 (2004).

Kamata T, Katsube K, Michikawa M, Yamada M, Takada S, Mizusawa H: R-spondin, a novel gene with thrombospondin type 1 domain, was expressed in the dorsal neural tube and affected in Wnts mutants. Biochim Biophys Acta 1676:51-60 (2004).

Karl J, Capel B: Sertoli cells of the mouse testis originate from the coelomic epithelium. Dev Biol 203:323-333 (1998).

- Kawase E, Hashimoto K, Pedersen RA: Autocrine and paracrine mechanisms regulating primordial germ cell proliferation. Mol Reprod Dev 68:5-16 (2004).

Kerr JB, Knell CM: The fate of fetal Leydig cells during the development of the fetal and postnatal rat testis. Development 103:535-544 (1988).

Kim Y, Kobayashi A, Sekido R, DiNapoli L, Brennan J, et al: Fgf9 and Wnt4 act as antagonistic signals to regulate mammalian sex determination. PLoS Biol 4:e187 (2006).

Kim Y, Bingham N, Sekido R, Parker KL, LovellBadge R, Capel B: Fibroblast growth factor receptor 2 regulates proliferation and Sertoli differentiation during male sex determination. Proc Natl Acad Sci USA 104:1655816563 (2007).

Klein AM, Zaganjor E, Cobb MH: Chromatintethered MAPKs. Curr Opin Cell Biol 25:272277 (2013).

Koopman P, Gubbay J, Vivian N, Goodfellow P, Lovell-Badge R: Male development of chromosomally female mice transgenic for Sry. Nature 351:117-121 (1991).

Koubova J, Menke DB, Zhou Q, Capel B, Griswold MD, Page DC: Retinoic acid regulates sex-specific timing of meiotic initiation in mice. Proc Natl Acad Sci USA 103:2474-2479 (2006). 
Kurimoto K, Yabuta Y, Ohinata Y, Shigeta M, Yamanaka K, Saitou M: Complex genome-wide transcription dynamics orchestrated by Blimp1 for the specification of the germ cell lineage in mice. Genes Dev 22:1617-1635 (2008).

Laird DJ, Altshuler-Keylin S, Kissner MD, Zhou $\mathrm{X}$, Anderson KV: Ror2 enhances polarity and directional migration of primoridal germ cells. PLoS Genet 7:e1002428 (2011).

Lavery R, Chassot AA, Pauper E, Gregoire EP, Klopfenstein M, et al: Testicular differentiation occurs in absence of $R$-spondin 1 and Sox9 in mouse sex reversals. PLoS Genet 8: e1003170 (2012).

-Lawson KA, Dunn NR, Roelen BA, Zeinstra LM, Davis AM, et al: Bmp4 is required for the generation of primordial germ cells in the mouse embryo. Genes Dev 13:424-436 (1999).

Lee JD, Treisman JE: Sightless has homology to transmembrane acyltransferases and is required to generate active Hedgehog protein. Curr Biol 11:1147-1152 (2001).

Lei L, Spradling AC: Female mice lack adult germline stem cells but sustain oogenesis using stable primordial follicles. Proc Natl Acad Sci USA 110:8585-8590 (2013).

Leydig F: Zur Anatomie der maennlichen Geschlechtsorgane und Analdruesen der Saeugethiere. Z Wiss Zool 2:1-57 (1850).

Li Y, Zheng M, Lau YF: The sex-determining factors $S R Y$ and SOX9 regulate similar target genes and promote testis cord formation during testicular differentiation. Cell Rep 8:723733 (2014).

Liebermann DA, Hoffman B: MyD genes in negative growth control. Oncogene 17:3319-3329 (1998).

- Lintern-Moore S, Peters H, Moore GP, Faber M: Follicular development in the infant human ovary. J Reprod Fertil 39:53-64 (1974).

- Liu C, Peng J, Matzuk MM, Yao HH: Lineage specification of ovarian theca cells requires multicellular interactions via oocyte and granulosa cells. Nat Commun 6:6934 (2015).

Liu CF, Bingham N, Parker K, Yao HH: Sex-specific roles of beta-catenin in mouse gonadal development. Hum Mol Genet 18:405-417 (2009).

Loke J, Pearlman A, Radi O, Zuffardi O, Giussani $\mathrm{U}$, et al: Mutations in MAP3K1 tilt the balance from SOX9/FGF9 to WNT/beta-catenin signaling. Hum Mol Genet 23:1073-1083 (2014).

Love JJ, Li X, Case DA, Giese K, Grosschedl R, Wright PE: Structural basis for DNA bending by the architectural transcription factor LEF1. Nature 376:791-795 (1995).

-Maatouk DM, DiNapoli L, Alvers A, Parker KL, Taketo MM, Capel B: Stabilization of betacatenin in XY gonads causes male-to-female sex-reversal. Hum Mol Genet 17:2949-2955 (2008).

Maatouk DM, Mork L, Chassot AA, Chaboissier MC, Capel B: Disruption of mitotic arrest precedes precocious differentiation and transdifferentiation of pregranulosa cells in the perinatal Wnt4 mutant ovary. Dev Biol 383:295306 (2013).
Maekawa M, Kamimura K, Nagano T: Peritubular myoid cells in the testis: their structure and function. Arch Histol Cytol 59:1-13 (1996).

-Malki S, Nef S, Notarnicola C, Thevenet L, Gasca $S$, et al: Prostaglandin D2 induces nuclear import of the sex-determining factor SOX9 via its cAMP-PKA phosphorylation. EMBO J 24: 1798-1809 (2005).

Manuylov NL, Smagulova FO, Leach L, Tevosian SG: Ovarian development in mice requires the GATA4-FOG2 transcription complex. Development 135:3731-3743 (2008).

Matson CK, Murphy MW, Sarver AL, Griswold MD, Bardwell VJ, Zarkower D: DMRT1 prevents female reprogramming in the postnatal mammalian testis. Nature 476:101-104 (2011).

-McLaren A: Meiosis and differentiation of mouse germ cells. Symp Soc Exp Biol 38:7-23 (1984).

McLaren A: Development of the mammalian gonad: the fate of the supporting cell lineage. Bioessays 13:151-156 (1991).

-McLaren A, Buehr M: Development of mouse germ cells in cultures of fetal gonads. Cell Diff Dev 31:185-195 (1990).

McLaren A, Southee D: Entry of mouse embryonic germ cells into meiosis. Dev Biol 187: 107-113 (1997).

- Memon MA, Anway MD, Covert TR, Uzumcu M, Skinner MK: Transforming growth factor beta (TGFbeta1, TGFbeta2 and TGFbeta3) null-mutant phenotypes in embryonic gonadal development. Mol Cell Endocrinol 294: 70-80 (2008).

-Mendis SH, Meachem SJ, Sarraj MA, Loveland KL: Activin A balances Sertoli and germ cell proliferation in the fetal mouse testis. Biol Reprod 84:379-391 (2011).

Menke DB, Koubova J, Page DC: Sexual differentiation of germ cells in XX mouse gonads occurs in an anterior-to-posterior wave. Dev Biol 262:303-312 (2003).

-Migrenne S, Pairault C, Racine C, Livera G, Geloso A, Habert R: Luteinizing hormone-dependent activity and luteinizing hormone-independent differentiation of rat fetal Leydig cells. Mol Cell Endocrinol 172:193-202 (2001).

Miles DC, van den Bergen JA, Sinclair A, Western PS: Regulation of the female mouse germ cell cycle during entry into meiosis. Cell Cycle 9: 408-418 (2010).

-Miles DC, Wakeling SI, Stringer JM, van den Bergen JA, Wilhelm D, et al: Signaling through the TGF Beta-Activin Receptors ALK4/5/7 regulates testis formation and male germ cell development. PLoS One 8:e54606 (2013).

Miller JR, Moon RT: Signal transduction through beta-catenin and specification of cell fate during embryogenesis. Genes Dev 10:2527-2539 (1996).

Minkina A, Matson CK, Lindeman RE, Ghyselinck NB, Bardwell VJ, Zarkower D: DMRT1 protects male gonadal cells from retinoid-dependent sexual transdifferentiation. Dev Cell 29:511-520 (2014).
Miyake Z, Takekawa M, Ge Q, Saito H: Activation of MTK1/MEKK4 by GADD45 through induced $\mathrm{N}-\mathrm{C}$ dissocation and dimerizationmediated trans autophosphorylation of the MTK1 kinase domain. Mol Cell Biol 27:27652776 (2007).

Miyamoto Y, Taniguchi H, Hamel F, Silversides DW, Viger RS: A GATA4/WT1 cooperation regulates transcription of genes required for mammalian sex determination and differentiation. BMC Mol Biol 9:44 (2008).

- Moniot B, Declosmenil F, Barrionuevo F, Scherer G, Aritake K, et al: The PGD2 pathway, independently of FGF9, amplifies SOX9 activity in Sertoli cells during male sexual differentiation. Development 136:1813-1821 (2009).

-Moniot B, Farhat A, Aritake K, Declosmenil F, Nef S, et al: Hematopoietic prostaglandin D synthase (H-Pgds) is expressed in the early embryonic gonad and participates to the initial nuclear translocation of the SOX9 protein. Dev Dyn 240:2335-2343 (2011).

-Moniot B, Ujjan S, Champagne J, Hirai H, Aritake $\mathrm{K}$, et al: Prostaglandin D2 acts through the Dp2 receptor to influence male germ cell differentiation in the foetal mouse testis. Development 141:3561-3571 (2014).

Moreno SG, Attali M, Allemand I, Messiaen S, Fouchet P, et al: TGFbeta signaling in male germ cells regulates gonocyte quiescence and fertility in mice. Dev Biol 342:74-84 (2010).

Mork L, Maatouk DM, McMahon JA, Guo JJ, Zhang P, et al: Temporal differences in granulosa cell specification in the ovary reflect distinct follicle fates in mice. Biol Reprod 86:37 (2012).

Mosimann C, Hausmann G, Basler K: Betacatenin hits chromatin: regulation of Wnt target gene activation. Nat Rev Mol Cell Biol 10: 276-286 (2009).

Mukhopadhyay S, Rohatgi R: G-protein-coupled receptors, Hedgehog signaling and primary cilia. Semin Cell Dev Biol 33:63-72 (2014).

Nef S, Verma-Kurvari S, Merenmies J, Vassalli JD, Efstratiadis A, et al: Testis determination requires insulin receptor family function in mice. Nature 426:291-295 (2003).

Nicol B, Yao HH: Gonadal identity in the absence of pro-testis factor SOX9 and pro-ovary factor beta-catenin in mice. Biol Reprod 93:35 (2015).

Norris DP, Grimes DT: Developmental biology. Cilia discern left from right. Science 338:206207 (2012).

Nusse R, Brown A, Papkoff J, Scambler P, Shackleford G, et al: A new nomenclature for int-1 and related genes: the Wnt gene family. Cell 64:231 (1991).

Nygaard MB, Almstrup K, Lindbaek L, Christensen ST, Svingen T: Cell context-specific expression of primary cilia in the human testis and ciliary coordination of Hedgehog signalling in mouse Leydig cells. Sci Rep 5:10364 (2015).

-Oh EC, Katsanis N: Context-dependent regulation of Wnt signaling through the primary cilium. J Am Soc Nephrol 24:10-18 (2013). 
-Ohinata Y, Payer B, O’Carroll D, Ancelin K, Ono $\mathrm{Y}$, et al: Blimp1 is a critical determinant of the germ cell lineage in mice. Nature 436:207213 (2005).

-Ohinata Y, Ohta H, Shigeta M, Yamanaka K, Wakayama T, Saitou M: A signaling principle for the specification of the germ cell lineage in mice. Cell 137:571-584 (2009).

-Orr-Urtreger A, Bedford MT, Burakova T, Arman E, Zimmer Y, et al: Developmental localization of the splicing alternatives of fibroblast growth factor receptor-2 (FGFR2). Dev Biol 158:475-486 (1993).

Orth JM: Proliferation of Sertoli cells in fetal and postnatal rats: a quantitative autoradiographic study. Anat Rec 203:485-492 (1982).

Pan D: The Hippo signaling pathway in development and cancer. Dev Cell 19:491-505 (2010).

- Parma P, Radi O, Vidal V, Chaboissier MC, Dellambra E, et al: R-spondin1 is essential in sex determination, skin differentiation and malignancy. Nat Genet 38:1304-1309 (2006).

-Pearlman A, Loke J, Le Caignec C, White S, Chin L, et al: Mutations in MAP3K1 cause 46,XY disorders of sex development and implicate a common signal transduction pathway in human testis determination. Am J Hum Genet 87:898-904 (2010).

- Pedersen LB, Veland IR, Schroder JM, Christensen ST: Assembly of primary cilia. Dev Dyn 237:1993-2006 (2008).

-Pepling ME, Spradling AC: Female mouse germ cells form synchronously dividing cysts. Development 125:3323-3328 (1998).

Peters H, Himelstein-Braw R, Faber M: The normal development of the ovary in childhood. Acta Endocrinol 82:617-630 (1976).

Philibert P, Biason-Lauber A, Rouzier R, Pienkowski C, Paris F, et al: Identification and functional analysis of a new WNT4 gene mutation among 28 adolescent girls with primary amenorrhea and Mullerian duct abnormalities: a French collaborative study. J Clin Endocrinol Metabol 93:895-900 (2008).

-Philibert P, Biason-Lauber A, Gueorguieva I, Stuckens C, Pienkowski C, et al: Molecular analysis of WNT4 gene in four adolescent girls with Mullerian duct abnormality and hyperandrogenism (atypical Mayer-Rokitansky-Kuster-Hauser syndrome). Fertil Steril 95:2683-2686 (2011).

Pierucci-Alves F, Clark AM, Russell LD: A developmental study of the Desert hedgehog-null mouse testis. Biol Reprod 65:1392-1402 (2001).

Pitetti JL, Calvel P, Romero Y, Conne B, Truong $\mathrm{V}$, et al: Insulin and IGF1 receptors are essential for XX and XY gonadal differentiation and adrenal development in mice. PLoS Genet 9:e1003160 (2013).

-Plotnikov AN, Schlessinger J, Hubbard SR, Mohammadi M: Structural basis for FGF receptor dimerization and activation. Cell 98:641650 (1999).
Polanco JC, Wilhelm D, Davidson TL, Knight D, Koopman P: Sox10 gain-of-function causes $\mathrm{XX}$ sex reversal in mice: implications for human 22q-linked disorders of sex development. Hum Mol Genet 19:506-516 (2010).

Porter JA, Young KE, Beachy PA: Cholesterol modification of hedgehog signaling proteins in animal development. Science 274:255-259 (1996).

Rastetter RH, Bernard P, Palmer JS, Chassot AA, Chen $\mathrm{H}$, et al: Marker genes identify three somatic cell types in the fetal mouse ovary. Dev Biol 394:242-252 (2014).

Richards AJ, Enders GC, Resnick JL: Activin and TGFbeta limit murine primordial germ cell proliferation. Dev Biol 207:470-475 (1999).

Robbins DJ, Fei DL, Riobo NA: The Hedgehog signal transduction network. Sci Signal 5:re6 (2012).

Ross A, Munger S, Capel B: Bmp7 regulates germ cell proliferation in mouse fetal gonads. Sex Dev 1:127-137 (2007).

Ross MH, Long IR: Contractile cells in human seminiferous tubules. Science 153:1271-1273 (1966).

-Sarraj MA, Escalona RM, Umbers A, Chua HK, Small C, et al: Fetal testis dysgenesis and compromised Leydig cell function in Tgfbr3 (beta glycan) knockout mice. Biol Reprod 82:153162 (2010).

-Satir P, Christensen ST: Overview of structure and function of mammalian cilia. Ann Rev Phys 69:377-400 (2007).

-Schepers G, Wilson M, Wilhelm D, Koopman P: SOX8 is expressed during testis differentiation in mice and synergizes with SF1 to activate the Amh promoter in vitro. J Biol Chem 278:28101-28108 (2003).

-Schlessinger J, Plotnikov AN, Ibrahimi OA, Eliseenkova AV, Yeh BK, et al: Crystal structure of a ternary FGF-FGFR-heparin complex reveals a dual role for heparin in FGFR binding and dimerization. Mol Cell 6:743-750 (2000).

-Schmahl J, Eicher EM, Washburn LL, Capel B: Sry induces cell proliferation in the mouse gonad. Development 127:65-73 (2000).

-Schmahl J, Kim Y, Colvin JS, Ornitz DM, Capel B: Fgf9 induces proliferation and nuclear localization of FGFR2 in Sertoli precursors during male sex determination. Development 131: 3627-3636 (2004)

- Sekido R, Lovell-Badge R: Sex determination involves synergistic action of SRY and SF1 on a specific Sox9 enhancer. Nature 453 :930-934 (2008).

-Sekido R, Bar I, Narvaez V, Penny G, LovellBadge R: SOX9 is up-regulated by the transient expression of $S R Y$ specifically in Sertoli cell precursors. Dev Biol 274:271-279 (2004).

Sertoli E: Dell' esistenza di particulari cellule ramificate nei canalicoli seminiferi del testicolo umano. Morgagni 7:31-40 (1865).

Sharpe RM, McKinnell C, Kivlin C, Fisher JS: Proliferation and functional maturation of Sertoli cells, and their relevance to disorders of testis function in adulthood. Reproduction 125:769-784 (2003).
Shi Y, Massague J: Mechanisms of TGF-beta signaling from cell membrane to the nucleus. Cell 113:685-700 (2003).

- Siggers P, Carre GA, Bogani D, Warr N, Wells S, et al: A novel mouse Fgfr2 mutant, hobbyhorse (hob), exhibits complete XY gonadal sex reversal. PLoS One 9:e100447 (2014).

-Skinner MK, Tung PS, Fritz IB: Cooperativity between Sertoli cells and testicular peritubular cells in the production and deposition of extracellular matrix components. J Cell Biol 100:1941-1947 (1985).

- Souquet B, Tourpin S, Messiaen S, Moison D, Habert R, Livera G: Nodal signaling regulates the entry into meiosis in fetal germ cells. Endocrinology 153:2466-2473 (2012).

-Speed RM: Meiosis in the foetal mouse ovary. I. An analysis at the light microscope level using surface-spreading. Chromosoma 85:427-437 (1982).

-Spemann H, Mangold H: Über Induktion von Embryonalanlagen durch Implantation artfremder Organisatoren. Arch Mikroskop Anat Entwicklungsmech 100:599-638 (1924).

- Spiller C, Wilhelm D, Koopman P: Cell cycle analysis of fetal germ cells during sex differentiation in mice. Biol Cell 101:587-598 (2009).

- Spiller CM, Feng CW, Jackson A, Gillis AJ, Rolland $\mathrm{AD}$, et al: Endogenous Nodal signaling regulates germ cell potency during mammalian testis development. Development 139: 4123-4132 (2012).

-Suzuki A, Saga Y: Nanos2 suppresses meiosis and promotes male germ cell differentiation. Genes Dev 22:430-435 (2008).

-Svingen T, Koopman P: Building the mammalian testis: origins, differentiation, and assembly of the component cell populations. Genes Dev 27:2409-2426 (2013).

Takekawa M, Posas F, Saito H: A human homolog of the yeast Ssk2/Ssk22 MAP kinase kinase kinases, MTK1, mediates stress-induced activation of the p38 and JNK pathways. EMBO J 16:4973-4982 (1997).

-Takeuchi Y, Molyneaux K, Runyan C, Schaible K, Wylie C: The roles of FGF signaling in germ cell migration in the mouse. Development 132:5399-5409 (2005).

Tam PP, Snow MH: Proliferation and migration of primordial germ cells during compensatory growth in mouse embryos. J Embryol Exp Morphol 64:133-147 (1981).

-Tang H, Brennan J, Karl J, Hamada Y, Raetzman L, Capel B: Notch signaling maintains Leydig progenitor cells in the mouse testis. Development 135:3745-3753 (2008).

Tani S, Kurooka H, Aoki T, Hashimoto N, Honjo $\mathrm{T}$ : The $\mathrm{N}$ - and C-terminal regions of RBP-J interact with the ankyrin repeats of Notch1 RAMIC to activate transcription. Nucleic Acids Res 29:1373-1380 (2001).

- Tevosian SG, Albrecht KH, Crispino JD, Fujiwara Y, Eicher EM, Orkin SH: Gonadal differentiation, sex determination and normal Sry expression in mice require direct interaction between transcription partners GATA4 and FOG2. Development 129:4627-4634 (2002). 
Thisse B, Thisse C: Functions and regulations of fibroblast growth factor signaling during embryonic development. Dev Biol 287:390-402 (2005).

Tien AC, Rajan A, Bellen HJ: A Notch updated. J Cell Biol 184:621-629 (2009).

Tobin JL, Beales PL: The nonmotile ciliopathies. Genet Med 11:386-402 (2009).

- Tomizuka K, Horikoshi K, Kitada R, Sugawara Y, Iba $\mathrm{Y}$, et al: R-spondin 1 plays an essential role in ovarian development through positively regulating Wnt-4 signaling. Hum Mol Genet 17:1278-1291 (2008)

-Toriello HV, Parisi MA: Cilia and the ciliopathies: an introduction. Am J Med Genet C Sem Med Genet 151C:261-262 (2009).

- Tremblay KD, Dunn NR, Robertson EJ: Mouse embryos lacking Smad1 signals display defects in extra-embryonic tissues and germ cell formation. Development 128:3609-3621 (2001).

Trombly DJ, Woodruff TK, Mayo KE: Suppression of Noth signaling in the neonatal mouse ovary decreases primordial follicle fomration. Endocrinology 150:1014-1024 (2009).

- Tsuda M, Sasaoka Y, Kiso M, Abe K, Haraguchi $S$, et al: Conserved role of nanos proteins in germ cell development. Science 301:12391241 (2003).

Turner N, Grose R: Fibroblast growth factor signalling: from development to cancer. Nat Rev Cancer 10:116-129 (2010).

-Uhlenhaut NH, Jakob S, Anlag K, Eisenberger T, Sekido R, et al: Somatic sex reprogramming of adult ovaries to testes by FOXL2 ablation. Cell 139:1130-1142 (2009).

Umehara F, Tate G, Itoh K, Yamaguchi N, Douchi $\mathrm{T}$, et al: A novel mutation of desert hedgehog in a patient with $46, \mathrm{XY}$ partial gonadal dysgenesis accompanied by minifascicular neuropathy. Am J Hum Genet 67:1302-1305 (2000).

-Vainio S, Heikkila M, Kispert A, Chin N, McMahon AP: Female development in mammals is regulated by Wnt-4 signalling. Nature 397: 405-409 (1999).

- Vanorny DA, Prasasya RD, Chalpe AJ, Kilen SM, Mayo KE: Notch signaling regulates ovarian follicle formation and coordinates follicular growth. Mol Endocrinol 28:499-511 (2014).

-Varjosalo M, Taipale J: Hedgehog: functions and mechanisms. Genes Dev 22:2454-2472 (2008).

-Vincent SD, Dunn NR, Sciammas R, ShapiroShalef $M$, Davis MM, et al: The zinc finger transcriptional repressor Blimp1/Prdm1 is dispensable for early axis formation but is required for specification of primoridal germ cells in the mouse. Development 132:13151325 (2005).
Waddington CH: Organisers \& Genes (The University Press, Cambridge 1940).

-Wainwright EN, Svingen T, Ng ET, Wicking C, Koopman P: Primary cilia function regulates the length of the embryonic trunk axis and urogenital field in mice. Dev Biol 395:342354 (2014).

Wakefield LM, Hill CS: Beyond TGFbeta: roles of other TGFbeta superfamily members in cancer. Nat Rev Cancer 13:328-341 (2013).

Waldeyer W: Eierstock und Ei (Engelmann, Leipzig 1870).

Warr N, Bogani D, Siggers P, Brixey R, Tateossian $\mathrm{H}$, et al: Minor abnormalities of testis development in mice lacking the gene encoding the MAPK signalling component, MAP3K1. PLoS One 6:e19572 (2011).

Warr N, Carre GA, Siggers P, Faleato JV, Brixey $\mathrm{R}$, et al: Gadd45gamma and Map3k4 interactions regulate mouse testis determination via p38 MAPK-mediated control of Sry expression. Dev Cell 23:1020-1031 (2012).

Weiss A, Attisano L: The TGFbeta superfamily signaling pathway. Wiley Interdiscip Rev Dev Biol 2:47-63 (2013).

-Western PS, Miles DC, van den Bergen JA, Burton M, Sinclair AH: Dynamic regulation of mitotic arrest in fetal male germ cells. Stem Cells 26:339-347 (2008).

Western PS, Ralli RA, Wakeling SI, Lo C, van den Bergen JA, et al: Mitotic arrest in teratoma susceptible fetal male germ cells. PLoS One 6:e20736 (2011).

Wilhelm D, Martinson F, Bradford S, Wilson MJ, Combes AN, et al: Sertoli cell differentiation is induced both cell-autonomously and through prostaglandin signaling during mammalian sex determination. Dev Biol 287: 111-124 (2005).

-Willerton L, Smith RA, Russell D, Mackay S: Effects of FGF9 on embryonic Sertoli cell proliferation and testicular cord formation in the mouse. Int J Dev Biol 48:637-643 (2004).

Wu Q, Kanata K, Saba R, Deng C, Hamada H, Saga Y: Nodal/activin signaling promotes male germ cell fate and suppresses female programming in somatic cells. Development 140:291-300 (2013)

-Wu Q, Fukuda K, Weinstein M, Graff JM, Saga Y: SMAD2 and p38 signaling pathways act in concert to determine XY primordial germ cell fate in mice. Development 142:575-586 (2015).

Yabuta Y, Kurimoto K, Ohinata Y, Seki Y, Saitou M: Gene expression dynamics during germline specification in mice identified by quantitative single-cell gene expression profiling. Biol Reprod 75:705-716 (2006)
Yamaji M, Seki Y, Kurimoto K, Yabuta Y, Yuasa $\mathrm{M}$, et al: Critical function of Prdm14 for the establishment of the germ cell lineage in mice. Nat Genet 40:1016-1022 (2008).

-Yan G, Fukabori Y, McBride G, Nikolaropolous S, McKeehan WL: Exon switching and activation of stromal and embryonic fibroblast growth factor (FGF)-FGF receptor genes in prostate epithelial cells accompany stromal independence and malignancy. Mol Cell Biol 13:4513-4522 (1993).

Yang SH, Sharrocks AD, Whitmarsh AJ: MAP kinase signalling cascades and transcriptional regulation. Gene 513:1-13 (2013)

Yao HH, Capel B: Disruption of testis cords by cyclopamine or forskolin reveals independent cellular pathways in testis organogenesis. Dev Biol 246:356-365 (2002).

-Yao HH, Whoriskey W, Capel B: Desert Hedgehog/Patched 1 signaling specifies fetal Leydig cell fate in testis organogenesis. Genes Dev 16: 1433-1440 (2002).

-Yao HH, DiNapoli L, Capel B: Meiotic germ cells antagonize mesonephric cell migration and testis cord formation in mouse gonads. Development 130:5895-5902 (2003).

Yao HH, Matzuk MM, Jorgez CJ, Menke DB, Page DC, et al: Follistatin operates downstream of Wnt4 in mammalian ovary organogenesis. Dev Dyn 230:210-215 (2004).

Yayon A, Klagsbrun M, Esko JD, Leder P, Ornitz DM: Cell surface, heparin-like molecules are required for binding of basic fibroblast growth factor to its high affinity receptor. Cell 64:841-848 (1991)

-Ying Y, Zhao GQ: Cooperation of endoderm-derived BMP2 and extraembryonic ectodermderived BMP4 in primordial germ cell generation in the mouse. Dev Biol 232:484-492 (2001).

- Ying Y, Liu XM, Marble A, Lawson KA, Zhao GQ: Requirement of Bmp8b for the generation of primordial germ cells in the mouse. Mol Endocrinol 14:1053-1063 (2000).

Zhang W, Bae I, Krishnaraju K, Azam N, Fan W, et al: CR6: a third member in the MyD118 \& Gadd 45 gene family which functions in negative growth control. Oncogene 18:4899-4907 (1999).

Zhang X, Ibrahimi OA, Olsen SK, Umemori H, Mohammadi M, Ornitz DM: Receptor specificity of the fibroblast growth factor family. The complete mammalian FGF family. J Biol Chem 281:15694-15700 (2006).

Zheng W, Zhang H, Gorre N, Risal S, Shen Y, Liu $\mathrm{K}$ : Two classes of ovarian primordial follicles exhibit distinct developmental dynamics and physiological functions. Hum Mol Genet 23: 920-928 (2014). 